\title{
LOS CAMBIOS Y DESAFÍOS QUE PLANTEA LA FISCALIDAD DE LA ECONOMÍA DIGITAL EN EL CONTEXTO INTERNACIONAL
}

\author{
THE CHANGES AND CHALLENGES POSED \\ BY THE TAXATION OF THE DIGITAL ECONOMY \\ IN THE INTERNATIONAL CONTEXT
}

\author{
Pedro Jesús Jiménez VARgas \\ Doctor profesor \\ Universidad Internacional de La Rioja
}

Recibido: 07.06.2021 / Aceptado: 25.06.2021

DOI: https://doi.org/10.20318/cdt.2021.6258

\begin{abstract}
Resumen: Una economía digital, es aquella que se centra en la venta de bienes y servicios a través de plataformas digitales. Ésta posee características muy específicas respecto a la economía tradicional. La imposición de los beneficios obtenidos a través de las transacciones efectuadas en la red, se han visto incrementadas de forma exponencial, la vez que han aumentado las ventas en el comercio digital, efectuadas por organizaciones empresariales internacionales que operan con o sin establecimiento permanente. Estas organizaciones empresariales, han desarrollado pautas generales para tratar de gravar sus ingresos en lugares con una baja o nula tributación. Uno de los principales problemas que se plantean en la activad e-commerce, es determinar, quién es el beneficiario efectivo final de las rentas obtenidas

Palabras clave: fiscalidad, beneficiario efectivo, economía digital, presencia digital, Normativa.

Abstract: A digital economy is one that focuses on the sale of goods and services through digital platforms. This has very specific characteristics with respect to the traditional economy. The taxation of profits obtained through transactions carried out on the network have been increased exponentially, at the same time that sales in digital commerce have increased, carried out by international business organizations that operate with or without a permanent establishment. These business organizations have developed general guidelines to try to tax their income in places with little or no taxation. One of the main problems that arise in e-commerce activity is to determine who is the final effective beneficiary of the income obtained.
\end{abstract}

Keywords: taxation, beneficial owner, digital economy, digital presence, Regulations.

Sumario: I. Introducción. II. Del Comercio electrónico a la economía digital. 1. Rasgos de la digitalización de los negocios tradicionales. 2. Definición y modalidades de comercio electrónico - III. Desafíos que plantea la economía digital en la fiscalidad internacional. 1. La economía digital y su problemática. 2. El beneficiario efectivo en la fiscalidad de las rentas internacionales. A. Introducción. B. Concepto y Origen. C. La figura del beneficiario efectivo en el Modelo de Convenio de la OCDE, en el Ordenamiento Jurídico Europeo y en la Legislación Española. IV. El nuevo concepto de establecimiento permanente en la economía digital. 1. Los nuevos factores del establecimiento permanente. 2. La presencia digital significativa. V. Conclusiones. 


\section{Introducción}

1. En la fiscalidad internacional existen factores que propician la elusión y la evasión en empresas vinculadas con la economía digital; está elusión está en relación con el lugar donde se genera el ingreso, y en la jurisdicción donde debería tributar. Por lo tanto, una de las de las grandes dificultades que presenta la economía digital se refiere a la tributación de los beneficios que generan las transacciones realizadas a través del comercio digital, carente de un espacio físico dentro de un espacio geográfico, es decir, a la carencia de un establecimiento permanente, que otorgue valor a los intangibles relacionados en el proceso comercial, que son en muchas ocasiones altamente trasladables a otras jurisdicciones. Fiscalmente, sabemos que el impuesto sobre la renta recae sobre las manifestaciones de riqueza celebrada en un territorio dado; en este caso, el propósito principal de este impuesto es que dicha riqueza sea tributada en la jurisdicción donde se encuentre la infraestructura física, legal y económica, y donde se celebre la prestación o venta.

2. Por otra parte, el Impuesto sobre el Valor Agregado (IVA) busca gravar la adquisición de bienes y servicios de cada etapa productiva, produciéndose la recaudación en el país de consumo del bien. Sin embargo, cuando hablamos de la economía digital, hablamos de un modelo en el cual, no existe infraestructura física, lo que genera dificultades para localizar la venta realizada. Con la economía digital, no se establece dependencia a un lugar físico, ya que se puede realizar la venta del bien o servicio sin que exista contacto físico entre el proveedor y su cliente. Respecto a la ausencia de infraestructura o establecimiento permanente, organismos internacionales como la Comisión Económica para América Latina y el Caribe (CEPAL), a través de su informe titulado el "Panorama Fiscal de América Latina y el Caribe $2020^{1 "}$ ", se refiere a la ausencia de presencia física en los siguientes términos:

«La digitalización de la economía también ha permitido que la mayoría de las empresas multinacionales participen activamente en algunos sectores especificos en distintos paises sin necesidad de que exista un establecimiento permanente en el pais, lo que ha dificultado la imposición efectiva sobre las rentas obtenidas en los países de origen».

3. De igual modo, la concepción actual de establecimiento permanente no es suficiente para reflejar la realidad de la economía actual; tal y como establece el último Modelo de la OCDE, en relación con los acuerdos para evitar una doble imposición. Debemos entender que existirá establecimiento permanente cuando exista un "lugar físico de negocio", en el cual, se realice la prestación de servicios o la venta de un bien inmueble. En la fiscalidad internacional es importante destacar el concepto establecimiento permanente a la hora de establecer la sujeción de las personas físicas o jurídicas a un impuesto determinado. En este sentido, es importante dejar claro que las leyes tributarias, establecidas por los Estados han creado un vínculo entre la persona o la empresa y el territorio, que es lo que determinará que esa persona o empresa pague el impuesto sobre la renta en un Estado concreto. Es de esta manera, como en la mayoría de las naciones del mundo, las compañías quedan sujetas a imposición por sus rentas obtenidas, a través del establecimiento permanente, con independencia del lugar de residencia de las mismas.

4. En realidad, cada país establece las diversas normas o reglas para definir la residencia de una empresa, sin embargo, muchos Estados optan por dos opciones: (i) el simple hecho de que la constitución legal de la compañía se haga efectiva en el país (ii) que el asiento y gestión de la compañía se realice desde ese país.

5. Cuando hablamos de establecimiento permanente, hacemos referencia a una forma jurídica a través de la cual, el sujeto pasivo se somete al pago de impuestos directos por los beneficios obtenidos en

\footnotetext{
${ }^{1}$ Comisión Económica para América Latina y el Caribe (CEPAL), Panorama Fiscal de América Latina y el Caribe, 2020 (LC/PUB.2020/6-P), Santiago, 2020.
} 
territorios extranjeros, cuya legislación es distinta a la del territorio de residencia de su residencia habitual. De esta forma, podremos determinar donde se encuentra el "beneficiario efectivo" de las rentas obtenidas en un determinado territorio. En este punto, se nos plantean distintas cuestiones en materia de economía digital, que nos llevan a cuestionarnos: ¿Cómo podemos identificar cuál es la jurisdicción en la que se genera el Valor? o, ¿Cuál será la jurisdicción en la que se deberá tributar o pagar el impuesto?, o bien, ¿Cómo se debe adaptar el concepto "establecimiento permanente" a la nueva realidad de la economía digital?

6. En el presente documento se intentará determinar cuál podría ser el nexo para establecer una presencia económica significativa, que nos ayude a delimitar el concepto de beneficiario efectivo a efectos fiscales, particularmente en las operaciones llevadas a cabo por empresas que evitan una presencia física en aquellos mercados donde operan, para evadir el impuesto correspondiente con la consiguiente erosión fiscal para los Estados. Para dar una respuesta, a los desafíos que presenta esta problemática de la economía digital, inicialmente analizaremos los rasgos de la digitalización del comercio tradicional, la problemática de la economía digital, los nuevos factores a tener en cuenta en el nuevo concepto de establecimiento y, los mecanismos y soluciones que nos ofrecen organizaciones como la OCDE para delimitar una presencia digital significativa.

\section{Del comercio electrónico a la economía digital}

\section{Rasgos de la digitalización de los negocios tradicionales}

7. En el ámbito internacional, actual, conviven dos modelos diferentes de política económica: por un lado, podemos clasificar el modelo que ha prevalecido durante los años previos a la aparición de internet y, por otro lado, podemos establecer el modelo de "economía digital". Actualmente se puede afirmar que la economía digital ha absorbido los aspectos más relevantes de la economía tradicional clásica; a su vez, este nuevo modelo de economía se ha consolidado gracias a la evolución de las nuevas tecnologías, que han permitido realizar actividades o negocios en línea en una proporción incluso mayor que a través de una presencia física en un determinado territorio.

8. Ante esta situación, la primera pregunta que debemos plantearnos es ¿Qué es la economía digital?; la pregunta no es baladí, he intentaremos responderla en los epígrafes siguientes. En este sentido, la doctrina económica se ha venido pronunciando sobre el fenómeno de la económica digital; y así, autores como ZIMMERMANN y KOERNER ${ }^{2}$, definen este tipo de economía como:

«Una economía basada en la digitalización de la información y la infraestructura de las TIC»; para otros autores como DEL AGUILA 3 , «este concepto es el que mejor define el impacto global de las TIC, no sólo las tectologías basadas en Internet, sobre la economía».

9. A nivel económico, la economía digital ha supuesto un punto de inflexión en relación con las barreras de entrada y salida en el plano virtual. Esto significa que, si en un mercado físico las barreras suponen un verdadero desafío dentro del mercado tradicional, en una economía digital, las empresas digitales establecen los incentivos suficientes para ser más competitivas y, en consecuencia, desplazar a otras del mercado. En este sentido, es muy fácil reemplazar una función en la "nube" por otra; esta situación produce que cuando algunas empresas por alguna razón, no pueden crecer de forma significativa, ni mantener su participación en el negocio, el desarrollo de las TIC, hace que algunas de estas empresas puedan ser sustituidas por otras.

\footnotetext{
${ }^{2}$ Vid. H. Dieter Zimmermann y V. Koerner (1999) "Emerging Industrial Structures in the Digital Economy - the Case of the Financial Industry”. Association for Information Systems AIS Electronic Library (AISEL) pág.115.

${ }^{3}$ Vid. A.R. del Águlla Obra (2001) "La economía digital y su impacto en la empresa: bases teóricas y situación en España”. Boletín económico de ICE, Información Comercial Española núm.2705 pág.8.
} 
10. Otro desafío al que se enfrenta la economía digital está estrechamente relacionado tanto con los usuarios, como con las funciones comerciales o empresariales que se llevan a cabo. Las empresas digitales tienen menos necesidad de contratar personal de un determinado territorio, ya que cuentan con una mayor flexibilidad a la hora de elegir donde ubicar los servidores y demás recursos. Por lo tanto, un mismo usuario o trabajador puede llevar a cabo distintas operaciones desde su localización, y que estas se desarrollen en distintos países sin necesidad de estar físicamente en ninguno de ellos. A nivel empresarial supone una enorme ventaja controlar y gestionar desde determinados territorios su actividad y su relación con los clientes.

11. Para organizaciones como la OCDE (Organización para la Cooperación y Desarrollo Económicos), la economía digital está configurada en cuatro sectores, como son: las infraestructuras, las aplicaciones, el comercio electrónico y los nuevos intermediarios. Por otra parte, la misma organización en su Plan de acción BEPS ${ }^{4}$ establece que:

«La expansión de la economía digital también supone desafios para la fiscalidad internacional. La economía digital se caracteriza por basarse, como ninguna otra, en activos intangibles, por el uso masivo de datos (especialmente de los de carácter personal), por la adopción general de modelos comerciales poliédricos que aprovechan el valor de las externalidades generadas por los servicios gratuitos, y por la dificultad de determinar la jurisdicción bajo la que tiene lugar la creación de valor».

12. Algunas de las características o rasgos que nos permiten diferencial la economía digital de la economía tradicional o mercantil son las siguientes:

\section{El desarrollo y la explotación de activos intangibles, que son aspectos fundamentales de la eco- nomía digital. Su inversión y explotación desempeñan un papel clave en la creación de valor y crecimiento de las empresas de $e$-commerce.}

13. En primer lugar, debemos hacer una distinción entre activos intangibles necesarios, y activos intangibles no esenciales. Los intangibles son parte fundamental de la actividad empresarial y, debido a su especial configuración suelen tener un elevado coste en investigación y desarrollo I+D.

14. Por otra parte, en relación con la economía digital uno de los principales problemas que se presentan, es la identificación y cuantificación de su valor, ya que estamos hablando de bienes inmateriales. Esta inmaterialidad provoca distorsiones en la cadena de valor en cuanto a lo que implica la creación de mismo; situación que puede producirse en aquellas actividades comerciales que solo concentran su valor en determinados activos intangibles que son difícil de valorar. En un primer término, abordaremos las oportunidades derivadas de las transacciones de bienes intangibles, los llamados "bienes o contenidos digitales" que ofrece el comercio electrónico, mediante la ejecución de todo un proceso de compra y entrega de bienes "vía online". También, mencionaremos las ventas de servicios intangibles que, si bien pueden adquirirse vía Web, solo se podrán brindar de manera efectiva fuera de la red, por ejemplo, reserva de viajes, alojamientos turísticos etc.

15. Dentro de la cadena de valor existen varios procesos comerciales que van desde su desarrollo y producción, hasta la venta al cliente final; estos procesos han experimentado profundos cambios que han derivado de la implantación de Internet, como catalizador que incide en la forma de consumir los contenidos y, a su vez, en la forma de distribuirlos y venderlos, es decir, una nueva configuración de la cadena de valor. Esta nueva configuración favorece la aparición de modelos de negocio que, a su

\footnotetext{
${ }^{4}$ Proyecto OCDE/G20 de Erosión de la Base Imponible y Traslado de Beneficios. "Cómo abordar los desafíos Fiscales de la Economía Digital” Acción 1: pág.29. Recuperado en: https://www.oecd.org/ctp/Action-1-Digital-Economy-ESP-Preliminary-version.pdf
} 
vez, se adaptan a las nuevas formas de consumo y a la aparición de nuevos agentes que anteriormente no existían. Por lo tanto, aparecen nuevas oportunidades de negocio caracterizadas por el desarrollo de las plataformas y servicios digitales adaptados a estos nuevos hábitos, unos servicios cuyo acceso es ubicuo desde cualquier dispositivo móvil.

16. Por ejemplo, podemos mencionar los servicios de comunicaciones de banda ancha fija y móvil para servicios audiovisuales, o los servicios de las plataformas Over-the-Top (OTT) entre otros. Una plataforma de servicios OTT, es una plataforma que transmite, o difunde contenidos a diferentes dispositivos como: teléfonos inteligentes, tabletas, televisores inteligentes etc. y lo hace, a través de Internet. Una de las características de este tipo de plataformas es, que no requieren de una infraestructura de transmisión, pero sí, utilizan la red del proveedor; éstas pueden transmitir diferentes tipos de contenidos, pero hasta ahora los contenidos especializados en la distribución de material audiovisual son los que más han destacado. Una de las ventajas principales que proporcionan este tipo de plataformas es, que los usuarios pueden elegir el tipo de contenidos que más les gusta, en cualquier momento del día.

17. En cuanto a los proveedores de servicios audiovisuales, señalar que se ha producido un aumento sustancial de la demanda de contenidos digitales, que ha propiciado a su vez un crecimiento rápido en la industria de este tipo de contenidos, unos contenidos que a la vez se han ido adaptando a nuevos formatos (videojuegos, música, cine, publicaciones digitales etc.). Por ejemplo, en el caso de los videojuegos se ha ido sustituyendo de forma paulatina el videojuego de escritorio por una nueva generación de videoconsolas, consolidándose así nuevas formas de juegos online, que permite aprovechar aspectos como la sociabilidad en este tipo de juegos.

18. De esta forma, las funciones sociales que integran dichos dispositivos los transforman en una vía de ocio interactivo que va más allá del propio juego, facilitando a los usuarios completar la oferta con nuevos servicios en línea, redes sociales, o servicios en «streaming», entre otros. Todo este conglomerado se convierte en un nicho de oportunidades comerciales para emprendedores y empresarios en el mundo del sector digital. Por este motivo, el auge de modelos de distribución en línea, están contribuyendo a la aparición de numerosos estudios donde se manifiesta que las empresas de sector digital se están beneficiando con la reducción de costes que se produce en el desarrollo de la actividad virtual.

19. Por otra parte, existen tecnologías que ofrecen distintas formas de generar vivencias, y nuevas formas de consumo audiovisual, que están facilitando el desarrollo de programas perfectamente adaptables a los hábitos y exigencias de los clientes, por ejemplo, el cliente queda inmerso en el videojuego, hecho que representa una oportunidad importante en el sector digital, debido a que este perfil de cliente tiene la posibilidad de sentirse identificado con el producto, favoreciéndose de este modo la compra de esta clase de contenidos. En otra línea, existen aplicaciones de realidad virtual relacionadas con campos como el de la medicina, la seguridad y, o la prevención de riesgos laborales entre otros, muy importantes para el conjunto de la población. En definitiva, una nueva forma de consumo, que desde nuestro punto de vista genera nuevas oportunidades no solo para la industria del sector software, sino también, para otros sectores como los mencionados anteriormente, y otros como el editorial, donde el mundo digital, además de haberle permitido encontrar nuevas fórmulas para incrementar sus ganancias con la digitalización, han fidelizado sus consumidores. En el mundo editorial estas fórmulas pasan por la suscripción de sus clientes a un catálogo disponible donde éstos pueden acceder y bajarse un número ilimitado de obras, sin que exista intermediario físico de por medio, con la consiguiente reducción de costes para la editorial.

20. Otra ventaja que proporciona la digitalización del sector editorial, pasa por la autoedición, donde los autores pueden editar sus propias obras, por medio de plataformas de autoedición; en este formato el autor ejerce el control sobre la edición, formato y comercialización, y su vez, la plataforma obtiene un porcentaje del beneficio por las copias digitales vendidas. Finalmente, un nuevo nicho de oportunidades lo encontramos en el consumo de noticias online. En este ámbito, cada vez son más los 
periódicos y revistas digitales que utilizan diferentes formatos de información, ya sea de forma escrita, o en forma de audio o video, para transmitir sus noticias, una tendencia alcista que se ha visto apoyada por el uso de los dispositivos móviles; como resultado se difunde una información instantánea y en línea, y desde nuestro punto de vista más actualizada y económica, factores que marcan la diferencia con la prensa tradicional.

\section{Los avances tecnológicos, permiten cada vez con más frecuencia que las empresas desarrollen su actividad económica-comercial, con una plantilla mínima, y en ocasiones casi inexistente. Esta actividad la pueden llevar a cabo tanto por redes sociales, como en línea a través distintos modelos de negocio.}

21. Los avances tecnológicos han adquirido una importancia relevante durante los últimos tiempos, debido a la fuerte socialización de Internet, una socialización que ha generado unos efectos en las redes sociales que han influido en la toma de decisiones tanto del comprador, como del vender.

22. De esta forma, podemos ver como las decisiones de un grupo de usuarios concreto, pueden influir en la toma de decisiones de otros, tal como sucede en las conocidas aplicaciones en las que se realizan descargas, "likes "o solo "clicks" en un determinado asunto. En esta situación, la puesta en línea facilita enormemente la actividad comercial, ya que son los usuarios, quienes ubicados en diferentes partes del mundo contribuyen a ello. Seguidamente, establecemos las cinco causas principales por las que el e-commerce debe estar presente en las redes sociales:

1. En las redes sociales tenemos la posibilidad de generar comunidades de seguidores y fans con los que se puede establecer una comunicación bidireccional. Los clientes consumidores van a poder manifestar sus opiniones, ser escuchados y podrán recibir y obtener una mayor satisfacción.

2. En las redes sociales, existe la posibilidad de edificar nuestra imagen de marca, estar presente en las redes y demostrar que lo que vendemos es bueno. Además, podremos crear una marca distribuyendo su contenido a través de este tipo de redes.

3. Las redes sociales nos permitirán monitorizar nuestra reputación en línea, estar presente en estas redes nos permite identificar y reaccionar de forma inmediata en el caso de que un cliente o comprador se encuentre descontento y hable mal de nosotros. Estas situaciones son relevantes para poder gestionar nuestra actividad de cara al futuro, ya que está en juego nuestra imagen y nuestro prestigio.

4. Las redes sociales nos dan la posibilidad de vender nuestros productos, aunque existe esa posibilidad, no es aconsejable sustituir la tienda en línea por este tipo de redes, para ejecutar nuestras ventas; aunque puede ser una posibilidad, el e-commerce, nos brinda una mayor independencia para nuestro negocio.

5. Las redes sociales constituyen una fuente de captación de clientes y en consecuencia de ingresos cada vez más importante.

23. Cuando hablamos de modelos de negocio digital, hablamos de modelos comerciales multifacéticos o multilaterales, que son ampliamente aceptados tanto por usuarios, como por las organizaciones empresariales al establecer un negocio. Estos modelos se caracterizan por la presencia de una plataforma o intermediario común, en la que interactúan los usuarios conectados a ella, a través de su ordenador, desde distintas áreas geográficas de todo el mundo. De esta forma, todos estos usuarios realizan acciones que producen efectos colaterales externos, positivos o negativos, en otro grupo de usuarios.

24. Por lo tanto, este tipo de plataformas virtuales resultarán siempre atractivas para los usuarios, debido a que desde cualquier lugar del mundo existe la posibilidad de interactuar, con la única necesidad de contar con un dispositivo móvil, ordenador, o tableta, y conexión a la red. Aunque la 
economía digital se amolda y cambia una y otra vez, no obstante, podemos agruparla en tres modelos de negocio:

a) Mercados online: son aquellos mercados que funcionan a través de plataformas online, estas plataformas actúan como intermediarias entre el vendedor que ofrece sus productos, y el comprador o usuario final.

b) Plataformas de redes sociales: como hemos señalado anteriormente a través de las redes sociales los usuarios vendedores anuncian sus productos y bienes para que los usuarios compradores puedan elegir y posteriormente adquirir.

c) Buscadores de internet: los buscadores de internet son sistemas informáticos en manos de compañías, que están configurados mediante algoritmos que permiten a sus clientes finales buscar contenidos en la red de forma rápida y sencilla.

25. Los anteriores modelos de negocio, constituyen nuevas oportunidades de negocio a través del comercio digital, no obstante, también representan un importante desafío para las autoridades fiscales de los Estados donde operan las compañías digitales. Esta circunstancia, la intentaremos delimitar a lo largo del presente documento, en epígrafes sucesivos.

\section{La creación de valor en el contexto de la economía digital está supeditada en gran medida al manejo, procesamiento e intercambio de datos. Es por esto, su dependencia, y de aquí, la importancia de saber el manejo de grandes volúmenes de datos.}

26. Gran parte de las organizaciones empresariales usan determinados procedimientos para recabar información relativa tanto de sus consumidores, como de sus proveedores. Esta práctica es de gran utilidad para las empresas, ya que, entre otras cuestiones, tienen la posibilidad de mejorar el servicio de cara a sus clientes, o bien, atender y reducir las posibles brechas de mercado donde éstas interactúan. La dependencia a este sistema "Big data" es absoluto, ya que actualmente es el único método que permite a las organizaciones conocer a sus clientes y proveedores sin necesidad de estar establecidas físicamente en una zona geográfica. Como resultado, se produce una reducción importante de costes en la actividad comercial. Para atender a estas cuestiones, es necesario que las organizaciones comiencen a desarrollar el intercambio de información a través de los medios digitales; por ejemplo, la gestión de pedidos, facturas, lista de precios, son solo el comienzo de la era donde la rapidez y la eficiencia en el intercambio de información son fundamentales para funcionamiento óptimo de la empresa a la hora de elegir sus productos.

27. Del mismo modo, es fundamental el manejo de un mismo lenguaje a la hora de aplicar los sistemas informáticos con los cuales se pretende interaccionar comercialmente. En cuanto al intercambio de datos conocido también como Electronic Data Interchange (EDI) es primordial buscar una comunicación empresarial estándar y digitalizada durante el intercambio de transacciones comerciales, que debe de acreditarse mediante documentos comerciales. EDI, es una manera estandarizada y organizada de desarrollar un negocio digital a través de la transferencia directa de datos "sub-digitales", por lo tanto, podemos decir que el uso de este sistema aumenta la eficiencia de las operaciones comerciales, ofreciendo como resultado una mayor productividad en los procesos de la organización, debido a que disminuyen las transacciones en papel y la intervención de personas. Asimismo, EDI marca las pautas de la estructuración de la documentación electrónica, para que se transmita de forma eficiente al lugar donde se produce el intercambio, desarrollado a través de software informático, que actúa como una interfaz a través de la cual se puede intercambiar la información comercial, por ejemplo, facturas, pedidos, documentos aduaneros etc. Por lo tanto, con este proceso se optimizan las operaciones básicas de la empresa.

28. A la hora de mejorar los canales comunicación, es fundamental mantener buenas relaciones no solo entre vendedor y comprador, sino también con terceros, es decir, con otras compañías, entidades bancarias y entidades públicas; estas relaciones optimizarán aún más los canales de comunicación y la 
transmisión de la información. En este sentido, EDI, ofrece una serie de reglas mundiales que definen la estructura más conveniente en cada momento, facilitando de este modo las labores administrativas internacionales. El propósito principal de EDI, es satisfacer la necesidad de aglutinar los documentos comerciales de una empresa utilizando al mínimo la participación humana; en consecuencia, debido al proceso de automatización de proceso, se reducen costes, tiempo y movimientos. Hay que señalar que, aunque este sistema está dirigido al intercambio comercial entre empresas y consumidores, hoy en día, es utilizado por entes y organismos públicos. Por lo tanto, podemos resumir las ventajas de EDI en que: reduce costes de mano de obra; aumenta la eficiencia reduciendo errores y optimizando la velocidad del proceso; mejora la trazabilidad de los intercambios reduciendo el tiempo; mejora y, fortalece, las relaciones comerciales.

29. Finalmente, un factor a tener en cuenta en el proceso de intercambio de datos es la seguridad, y el control de acceso a la protección de datos ante posibles ataques informáticos, garantizando la integridad y confidencialidad en el intercambio de la información en todo momento, por lo que es necesario que tanto empresarios, como clientes, tengan una conexión segura a la red.

\section{La mayor capacidad de acceder a mercados internacionales lo que incrementa considerable- mente la posibilidad de suministrar bienes y de prestar servicios más allá de las fronteras.}

30. En el año 2020, el comercio electrónico logro. facturar aproximadamente unos 1.655 billones de euros en todo el mundo, y para el 2023, se espera que supere los 2.300 billones. Aun así, hoy en día el comercio tradicional sigue generando más confianza en la población que el comercio electrónico. En 2020 el comercio electrónico representó aproximadamente el 14\% de las ventas totales en el mucho, y para el año 2021 se prevé que esta cifra se eleve al 17,5\%.

31. Es evidente que la industria del comercio electrónico está en continuo crecimiento, del mismo modo que cada día surgen nuevos mercados de comercio electrónico que pasaran a engrosar las cifras anteriormente descritas. A partir de esta conceptualización, la OCDE establece que ${ }^{5}$ :

«El éxito y la expansión de las empresas dependen también, de modo decisivo, de su capacidad de competir en el nuevo entorno económico, que las TIC están contribuyendo a configurar. Pese a la disponibilidad universal de las TIC, su uso sigue variando entre empresas, particulares y países».

32. A continuación, describiremos a groso modo distintos mercados en el comercio electrónico entre los que se encuentran los más grandes del mundo, y lo haremos en términos de ventas B2c del país.

33. En la actualidad, China es el mercado de comercio electrónico más grande del mundo, liderado por filiales comerciales de grupos como: Alibaba, Taobao o Tmall entre otros. En cifras, China posee una tasa de crecimiento anual del $35 \%$ y, es uno de los mercados internacionales que con mayor rapidez está creciendo. En ventas online según Kinsta ${ }^{6}$, en 2019 alcanzó los 672.000 millones de dólares, lo que representó el 15,9\% en las ventas minoristas totales de ese año. Durante muchos años Estados Unidos ha liderado las ventas en comercio electrónico, pero en la actualidad se configura como el segundo mercado más grande del mundo. A través de gigantes como Amazon, eBAY, o Walmart, en Estados Unidos se observa un crecimiento en las ventas durante los últimos años; en cifras, las ventas online alcanzaron los 340.000 millones de dólares que representa el 7,5\% de las ventas minoristas totales. (datos según Kinsta).

\footnotetext{
${ }^{5}$ Perspectivas de la OCDE sobre la economía digital 2015, pág. 149. Recuperado en: https://www.oecd.org/sti/ieconomy/ DigitalEconomyOutlook2015 SP WEB.pdf

${ }^{6}$ KInSTA: proveedor de WordPress. Recuperado en: https://kinsta.com/es/blog/etadisticas-ecommerce/
} 
34. Continuando con otros Estados punteros en ventas en el comercio electrónico, Reino Unido a pesar de su pequeño tamaño en comparación con Estados Unidos o China, se consolida en el tercer lugar en ventas a través del e-commerce. En este país anglosajón, plataformas como Amazon UK, Argos y Play son los sitios web preferidos, y los que tienen un porcentaje más alto de ventas minoristas en relación al comercio digital; con una facturación aproximada de 200.000 millones de euros en 2019, representan el 14,5\% de las ventas minoristas totales. Por su parte, Japón ocupa el cuarto lugar en el mundo, en ventas digitales con la peculiaridad de que es líder en comercio móvil, un comercio que se realiza a través, de dispositivos móviles como smartphones o tablets, incluyendo también el pago. La plataforma más utilizada en el país nipón es Rakuten. En Japón las ventas online según el portal Statista alcanzaron la cifra de 80.762 millones de euros, o lo que es igual el 5,4\% de las ventas minoristas totales. En el caso de Europa, tendremos que llegar a Alemania para encontrar el primer país de la Unión Europea que se encuentra dentro del ranking de ventas a nivel mundial en comercio electrónico.

35. En Alemania, será a través de plataformas como Amazon y eBay donde se realizan la mayor parte de las ventas digitales en este país. En el año 2019 según un estudio encargado por Asociación Alemana de Comercio Electrónico y Orden por Correo (bevh) ${ }^{7}$ fueron 72.600 millones de euros, el montante por las ventas a través del comercio digital, que supusieron el 8,4\% de las ventas minoristas totales. Continuando en la Unión Europea, Francia se configura como el segundo país comunitario y quinto en mundo en cuanto a ventas digitales se refiere, unas ventas que se efectúan en plataformas como Odigeo y Cdiscount, que mantienen la ventaja sobre su inmediato competidor estadounidense Amazon, que también está implantada en territorio galo. Las ventas en Francia en 2019 ascendieron según datos publicados por la Federación de Comercio Electrónico francesa (Fevad) ${ }^{8}$ a 103.400 millones de euros, que representan una participación en el comercio electrónico y en las ventas minoristas totales del 5,1\%.Otros Estados a destacar son Corea del Sur, con 37.000 de dólares en ventas; Canadá con 30.000 millones de dólares o Rusia, que, a pesar de ser un país importante tanto por su tamaño, como por su población, alcanzo una cifra de 20.000 millones de dólares en 2019.

36. El comercio electrónico está en constante crecimiento, no solo en volumen de ventas, sino también en diversificación. A nivel geográfico, Asia y el Pacifico son unas de regiones en las que más se está apostando por el comercio digital, y donde se espera que durante los próximos años aumenten el volumen de negocio. Hasta muy recientemente, era el mercado norteamericano el que ocupaba ese lugar; encontrar nuevos espacios de venta conlleva implementar nuevos conocimientos en este mercado, y adaptar las estrategias de venta. Cada día a nivel internacional, las ventas transfronterizas van ganando mayor importancia, ya que se abren nuevas líneas de negocio para las empresas, que no tienen que invertir excesivamente para generar negocios en nuevos mercados. Finalmente creemos que vender en países limítrofes no solo implica establecer una logística importante, sino que también, que se pueden lograr buenos resultados con la estrategia correcta.

\section{Definición y modalidades de comercio electrónico}

37. Cuando hablamos de Tecnologías de la información (TI), nos referimos a aquellos elementos que durante los años han avanzado facilitando modelos de negocio innovadores que antes era impensable su presencia. El elemento común que comparte el uso de estas tecnologías es "Internet" (International Network of computers) cuya creación se produjo en los años sesenta del pasado siglo. Internet es un conjunto descentralizado de redes de comunicación interconectadas entre sí; en estas redes se almacenan diferentes tipos de información en el denominado "Portal" o "Plataforma digital", y es a través de estas redes donde se han creado distintos modelos de negocio basados en los servicios de publicidad, la intermediación, el contenido, la comunidad, la integración con otros dispositivos tecnológicos y el comercio.

\footnotetext{
${ }^{7}$ BEVH: Asociación Alemana de Comercio Electrónico y Orden por Correo. Recuperado en: https://www.bevh.org/

${ }^{8}$ FEVAD: Federación de Comercio Electrónico Francesa; Recuperado en: https://www.fevad.com/indicateurs/
} 
38. Doctrinalmente son varias las definiciones que se han dado sobre "comercio electrónico" o, e-commerce (en inglés). Inicialmente la definición se limitaba a las transacciones realizadas electrónicamente, como el intercambio de información. Sin embargo, con el aumento de la popularidad de Internet a mediados de la década de los años noventa del pasado siglo, el intercambio de información se transformó, y comenzó a extenderse el concepto venta de servicios, estableciéndose la red en un medio de venta donde se usan como forma de pago otros medios electrónicos como son las tarjetas de crédito, las transferencias bancarias, plataformas de pago etc. A pesar de todo, en ese momento la definición de comercio electrónico solo se asocia al comercio por internet, y no se tiene en cuenta los diversos elementos que conforman hoy en día una operación de venta dentro de este ámbito. Una primera visión en esta dirección, la encontramos en autores como TORRES MANRIQUE ${ }^{9}$ cuando señala que:

«El comercio electrónico es el comercio que se realiza teniendo como intermediarios medios electrónicos, es decir, este tipo de comercio es el que se celebra a través de internet, que puede ser a través de una página web o de correos electrónicos, o de ambos al mismo tiempo, o de firma electrónica y firma digital».

39. Teniendo en cuenta el elevado número de operaciones que se realizan a través de Internet, y que quedan fuera del ámbito fiscal, podemos decir, que esta definición es demasiado estricta, ya que existen otras definiciones donde se da más cabida a la naturaleza civil y mercantil.

40. Otra definición acota el concepto a aquellos bienes que solamente pueden venderse en vía telemática; es el caso de NOCETE CORREA ${ }^{10}$, el comercio electrónico:

«Es aquel constituido por aquellas transacciones de bienes o prestaciones de servicios, indicadoras de capacidad económica, en las que la transmisión del bien o la prestación del servicio se realizan, íntegramente, mediante la utilización de tecnologías telemáticas».

41. En la normativa española ${ }^{11}$, la definición de comercio electrónico, está en consonancia con la establecida por la Unión Europea en la Directiva. 2000/31/CE ${ }^{12}$; además, es considerado como servicio de la sociedad de la información donde el comercio electrónico es:

«Cualquier servicio prestado a distancia, normalmente a títulooneroso, mediante un equipo electrónico para el tratamiento (incluida la compresión digital) y el almacenamiento de datos, y a petición individual del receptor del servicio».

42. A nivel internacional, una de las primeras organizaciones en establecer una definición sobre comercio electrónico fue OCDE, en 1997, para esta organización, el comercio electrónico es aquel que: «incluye todas las transacciones comerciales, tanto entre organizaciones como entre individuos, que se basan en la transmisión y proceso de datos digitales, incluyendo el texto, el sonido y las imágenes».

43. En el año 2000 la organización actualizó tal definición, y lo hizo mediante dos definiciones ${ }^{13}$ :

- Definition broad (amplia definición): «una transacción electrónica es la venta o compra de bienes o servicios, ya sea entre negocios, hogares, individuos, gobiernos y otras organizaciones privadas, realizadas a través de redes informáticas. Los bienes y servicios son

\footnotetext{
${ }^{9}$ Vid. F. J. Torres Manrique (2008) “Comercio electrónico”. Revista Derecho y Cambio Social núm. 15.

${ }^{10} \mathrm{Vid}$. F. Nocete Correa (2006) "La fiscalidad del comercio electrónico”. Crónica tributaria núm.120 pág. 113.

${ }^{11}$ Ley 34/2002, de 11 de julio, de servicios de la sociedad de la información y de comercio electrónico. Recuperado en: https://www.boe.es/buscar/act.php?id=BOE-A-2002-13758

${ }^{12}$ Directiva 2000/31/CE del Parlamento Europeo y del Consejo, de 8 de junio de 2000, (Directiva sobre el comercio electrónico). Recuperado en: https://www.boe.es/buscar/doc.php?id=DOUE-L-2000-81295

${ }^{13}$ THE OECD DEFINITIONS OF INTERNET AND E-COMMERCE TRANSACTIONS (2019). Recuperado en: https:// www.oecd.org/sti/ieconomy/2771174.pdf
} 
ordenado a través de esas redes, pero el pago y en la entrega final del bien o servicio puede ser realizado en o fuera de línea».

Incluye: pedidos recibidos o realizados en cualquier aplicación en línea utilizada, automatizando transacciones como aplicaciones de Internet, EDI, Minitel o sistemas telefónicos interactivos.

- Definition narrow (definición corta): «una transacción por Internet es la venta o compra de bienes o servicios, ya sea entre negocios, hogares, individuos, gobiernos y otras organizaciones privadas, realizadas a través de Internet. los bienes y servicios se ordenan a través de esas redes, pero el pago y la entrega final del bien o El servicio se puede realizar en línea o fuera de línea».

Incluye: pedidos recibidos o realizados en cualquier aplicación de internet utilizada, automatizando transacciones como páginas web, extranets y otras aplicaciones que se ejecutan en Internet, como EDI a través de Internet, Minitel a través de Internet o de cualquier otro sitio web habilitar la aplicación independientemente de cómo Se accede a la web (por ejemplo, a través de un móvil o un Televisor).

44. Por su parte, para la Organización Mundial del Comercio (OMC), el comercio electrónico es: «la producción, publicidad, venta y distribución de productos a través de las redes de telecomunicaciones».

45. Cuando utilizamos el concepto comercio a través de las redes, nos estamos refiriendo al "comercio electrónico", es decir, a la entrega de bienes y prestación de servicios realizados a través de la red. En este caso Internet se convierte en el principal canal de comunicación entre un proveedor y su cliente, sin que exista un establecimiento o presencia física donde tenga que desplazarse el cliente consumidor para adquirir su producto. En este tipo de operaciones es importante destacar el grado de intervención de las personas ya sean físicas, o jurídicas de cara a establecer su contribución al sistema impositivo de las haciendas estatales, según MERKX ${ }^{14}$ : «Los servicios solo se pueden calificar como "servicios electrónicos" cuando existe una mínima intervención humana».

46. En este caso, el grado de intervención humana debe evaluarse en función de las relaciones entre el prestador del servicio a través de la red y el cliente. Cuando se presta un servicio de esta naturaleza es cuando se analiza con detalle la incidencia de la intervención humana en este tipo de operaciones digitales. El comercio electrónico es una revolución autentica en el modo que se realizan las transac-

Volumen de negocio del comercio elctrónico B2 en España (Evolución 2009 - 2019) (Millones $€$ )

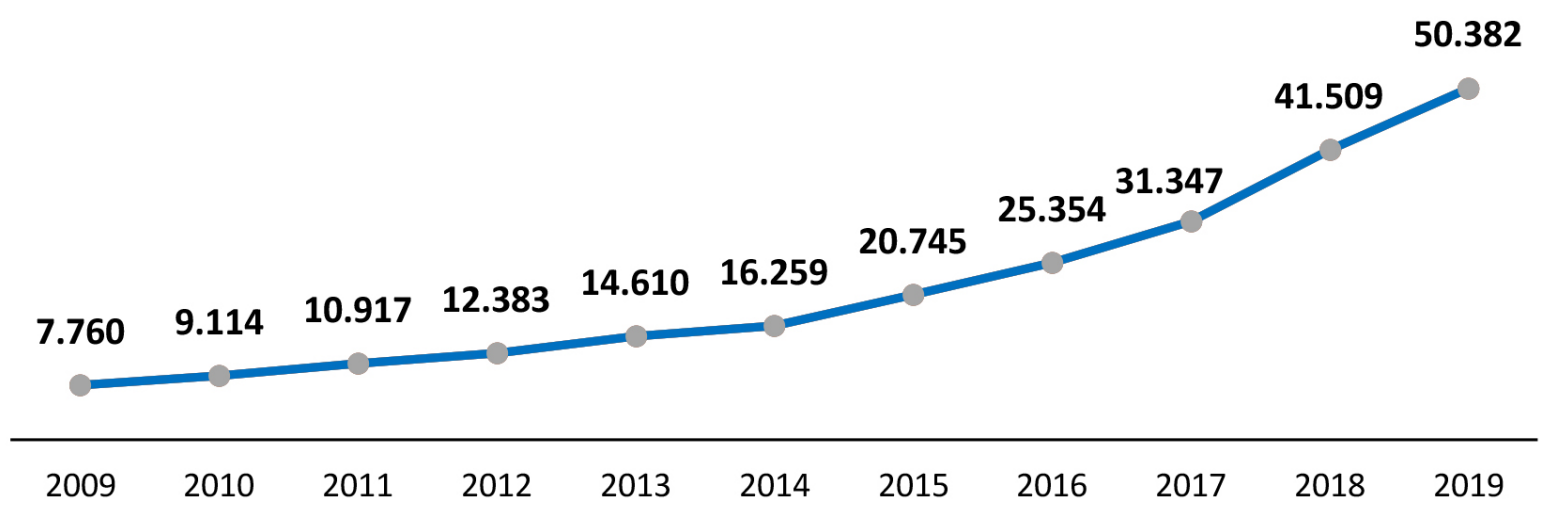

Fuente: encuesta INE y Encuesta online de comercio electrónico, ONTSI. (2018-2019).

${ }^{14}$ M. Merkx (2018) “Cuando la intervención humana es mínima International VAT Monitor” (Volumen 29), núm.1. 
Gasto medio anual por internauta comprador en comercio electrónico B2C en España (Evolución 2009-2019) (E)

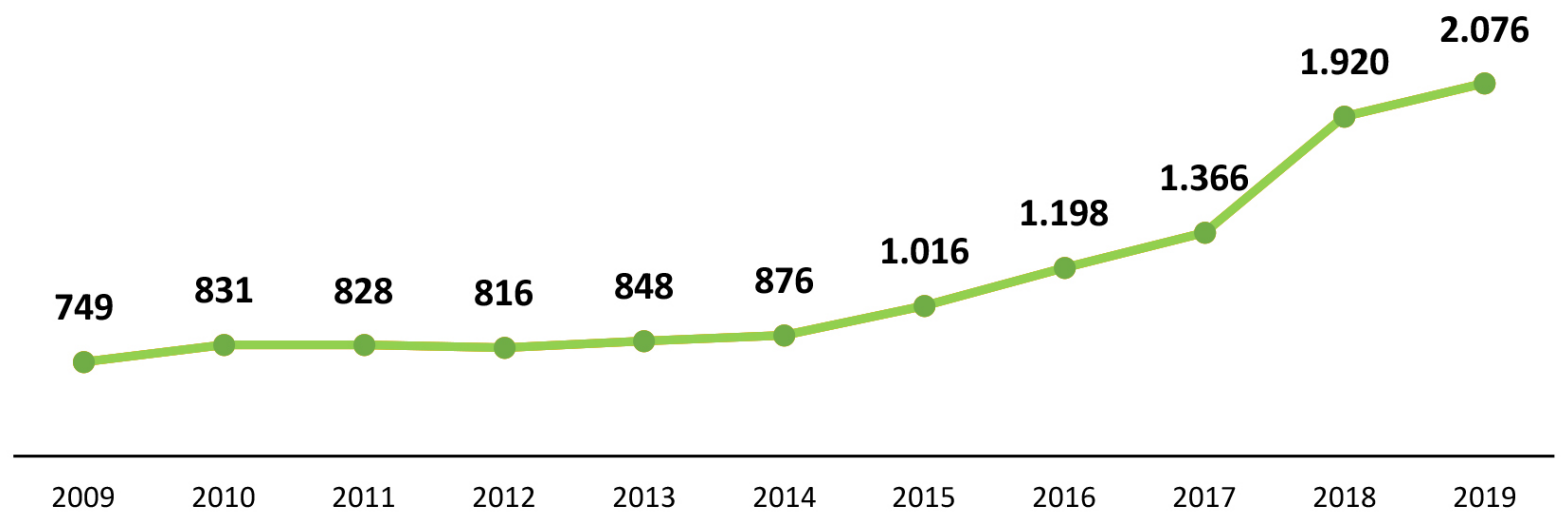

Fuente: encuesta INE y Encuesta online de comercio electrónico, ONTSI. (2018-2019).

ciones económicas; la compra y venta y la prestación de servicios se pueden realizar de infinitas formas, ya sea a través de páginas web, a través de plataformas digitales, o a través de redes sociales. Desde que existen registros, las ventas a través de internet han ido en tendencia ascendente hasta el punto de llegar a superar en España los 50.000 millones de euros en el año 2019, lo que supone un aumento de un 21,4\% más ( 8.873 millones de euros) respecto al año anterior. Durante el 2019 cada comprador internauta gastó de media unos 2.076 euros en compras vía comercio online, cifra que se ha duplicado desde 2015 cuando el gasto era de 1.016 euros por comprador, y 156 euros más respecto a 2018.

47. En cuanto al número de compradores la tendencia en España también ha sido al alza; tanto es así, que, en el año 2019 , un 76,4\% de la población, (24,3 millones de personas) efectuaron alguna compra a través de las redes, cifra que supone un incremento del 12,2\% con respecto al año 2018. Como

Internautas y compradores online en España (Evolución 2009.2019)

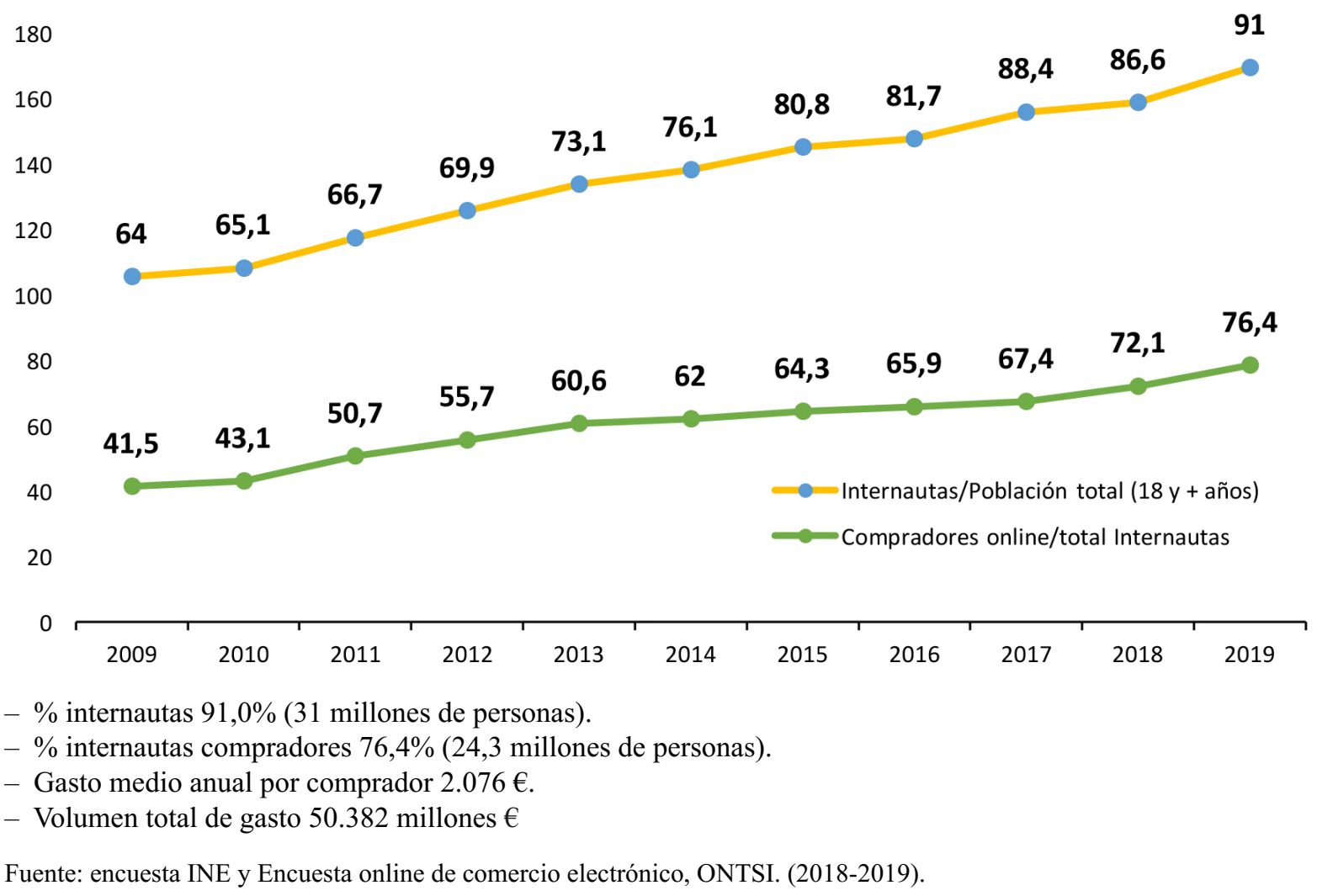


podemos comprobar las cifras son verdaderamente espectaculares, más aún, conociendo que, en España en el año 2019, utilizaba internet el $91 \%$ de la población, de los cuales tan solo $23,6 \%$ de ellos (unos 7 millones de personas) no efectuaron compra online alguna; el resto, sí.

48. En términos de cifras, los productos más demandados a través de la red por los internautas durante 2019, y de los 24,3 millones de compradores, el 59,2\% de éstos adquirieron calzado, ropa y complementos; el 52\% realizaron reservas de alojamiento y paquetes turísticos; un $49 \%$ compraron estradas para espectáculos y eventos; en billetes de transporte la cifra alcanza el 45,3\%; la compra de comida a domicilio alcanzo el $38 \%$ de las compras etc. Por volumen de gasto, serán los billetes de transporte y las reservas de alojamientos turísticos los que sobresalen en las compras online, compras que, en 2019, representaron el 30,9\% del gasto total, alcanzándose la cifra de 15.593 millones de euros. Una cifra importante de cara al futuro en relación al comercio digital es el porcentaje de compradores online de productos digitales, un porcentaje que pasa de del 3,7\% en 2018 al 11,8\% en 2019, un crecimiento en ventas que dobla al sufrido por la venta tradicional de productos físicos.

49. Estas cifras se ven aún más consolidadas, ya que los clientes internautas optan cada vez con más frecuencia a suscribirse a algún servicio o contenido digital de pago, una cifra que alcanzó los 10,5 puntos porcentuales en 2019. En este tipo de suscripciones destacan las suscripciones a plataformas digitales audiovisuales en «streaming»; un 94\% de los usuarios de internet se han suscrito en algún momento a algún tipo de plataformas de estas características; del mismo modo, un número importante de clientes han accedido a plataformas de juego de azar, apuesta de loterías etc. Como podemos observar, la economía digital ha crecido de forma exponencial durante los últimos años, algo que se debe en gran medida al uso de las nuevas tecnologías y de Internet. Esta realidad ha generado una dependencia a estos medios no solo para prestar servicios, sino para adquirir bienes. Por lo tanto, podemos afirmar que la economía digital es un modelo económico que incluye tanto a servicios gestionados a través de internet, como aquellos relacionados a las tecnologías de la información. En este caso, Internet es un instrumento fundamental en este mercado, para la comercialización y entrega de productos y servicios; además, es una herramienta que permite el intercambio de estos, de forma más rápida y a nivel global.

50. En una economía digital, cada vez son más frecuentes los negocios a través de una plataforma, donde no requiere de presencia física para el intercambio de productos y, o servicios; en cambio, el intercambio solo requiere de datos en línea (online) y de la gestión de los mismos. El comercio digital, ha flexibilizado en gran medida la economía tradicional modificada hasta el punto de que las empresas digitales han desterritorializado la actividad económica y su fiscalidad. Como establece SÁNCHEZARCHIDONA HIDALGO ${ }^{15}$ :

«Mediante el uso de internet se puede operar en cualquier mercado sin necesidad de una presencia fisica, lo que nos lleva a evitar la incidencia fiscal basada en el territorio o el criterio de permanencia asociado a la residencia. En definitiva, esta forma de operar provoca el efecto de desterritorializar la fiscalidad por el hecho de practicar un tipo de comercio que puede ser calificado de inmaterial».

51. La desterritorialización de la fiscalidad nos lleva a plantearnos la creación de nuevas reglas que impidan la erosión de las bases imponibles y el traslado de beneficios a Estados más favorables; cuestión que trataremos en sucesivos epígrafes.

52. El comercio digital ha cambiado los hábitos tradicionales de consumo; ahora nos encontramos con un consumidor virtual al que el comercio tradicional no le parece importar, ya que, para él, poder acceder al mercado sin tener que desplazarse ha acentuado aún más su zona de confort. Este consumidor final ha cambiado por tanto el panorama económico tradicional. Si los principales destinatarios

${ }^{15}$ Vid. G. SÁnchez-Archidona Hidalgo (2018) "Reflexión sobre los avances de la OCDE en la economía digital y su extrapolación a la economía colaborativa”, en Revista Aranzadi Doctrinal, núm. 1, pág. 168. 
de bienes y servicios cambian sus hábitos de consumo, las compañías y grandes empresas también lo deben de hacer, creando páginas web, y destinando parte de sus recursos para digitalizar su actividad de cara a ser más competitivo dentro del mercado digital. Según SÁNCHEZ-ARCHIDONA HIDALGO ${ }^{16}$ :

«Los Estados tienen gran parte de responsabilidad en la consecución de instrumentos y acciones coordinadas frente al fenómeno digital. Los Estados son los primeros interesados en la regulación de este fenómeno y los responsables de actuar de manera coordinada frente a los desafios actuales y futuros que plantea la economía digital, y eso sólo será posible si aúnan más esfuerzos de cara al futuro para adoptar soluciones conjuntas».

53. Entre los muchos desafíos a los que se enfrentan los Estados en la economía digital, además del fiscal, podemos establecer los siguientes:

i. La multiplicación de puntos de acceso: esta circunstancia afecta tanto en el ámbito tiempo, como en el espacio, ya que provoca menores restricciones, un aumento de la deslocalización de las empresas y por consiguiente de la propia fiscalidad.

ii. El incremento de la eficiencia empresarial: el incremento de la eficiencia en el nuevo contexto económico, provoca nuevos cambios en la comunicación interna de la empresa; por lo tanto, se deben introducir y difundir nuevos valores, y establecer nuevas pautas de gestión en el desarrollo organizacional.

iii. Aparición del "intermediario digital": en las transacciones digitales participan distintos sujetos con distintos roles; es decir, el cliente y el vendedor que ostentan sus propios roles; el problema puede aparecer cuando aparece la figura del intermediario, y el rol que éste puede adoptar; si entendemos que el operador de la plataforma es el mero intermediario cliente/vendedor, cuando hablamos de responsabilidad de las plataformas digitales hay que diferenciar entre plataformas intermediarias neutrales y las que ejercen un control sobre el servicio subyacente, es decir, entre el "intermediario digital" o el "prestador del servicio".

iv. La digitalización de la actividad económica: esta digitalización, genera numerosos cambios tanto en los hábitos, como en la forma de realizar las transacciones vendedor/cliente, entre los que están el ofrecimiento de servicios intangibles.

v. La utilización generalizada de unas pocas lenguas: el idioma es un factor decisivo en las compras online; en las plataformas de compra y venta es importante crear el contenido en varios idiomas, ya que el porcentaje de clientes extranjeros es muy elevado, por lo tanto, es importante ofrecer a los clientes una versión del producto adecuada a su propio idioma.

vi. La menor influencia de las pequeñas y medianas empresas en internet: aunque la digitalización es pieza fundamental para el crecimiento y desarrollo de las Pymes, la gestión y los recursos para implementar estas tecnologías son muchos más reducidos, que los que poseen las grandes empresas, por lo que su competitividad dentro del mercado digital es mucho menor.

vii. El reforzamiento del valor del capital humano en las empresas: la nueva economía digital plantea nuevos retos en el desarrollo humano, ya que se requiere un periodo de adaptación y una mayor cualificación específica para los cambios que exige la economía digital.

viii. La globalización económica: esta globalización representa importantes desafíos, ya que las nuevas características que presenta este tipo de economía digital, hacen que las transacciones se efectúen con mucha velocidad sin importar la procedencia de las partes.

54. Por otra parte, en cuanto a la forma en que se acuerdan las transacciones referentes a la economía digital, podemos establecer distintas modalidades que enunciamos a continuación:

${ }^{16}$ Vid. G. SÁnchez-Archidona Hidalgo (2016) "La influencia de la economía digital en el concepto de establecimiento permanente en un entorno post-beps”. Revista Quincena Fiscal num.13. Editorial Aranzadi S.A.U. 
- Transacciones entre empresas ("Business-to-Business", "B2B"). Nos encontramos ante un modelo de negocio donde las empresas venden sus productos o servicios de carácter digital a otra empresa; generalmente se relaciona con un comercio mayorista, aunque en ocasiones pueden establecerse prestaciones de servicios y consumo de contenidos. El proyecto de un B2B, se centra más en los proveedores de bienes y servicios, que en la demanda de los clientes. Este modelo se centra en las cualidades objetivas del producto en el mercado y en su funcionalidad. Una empresa presta servicios a otra que se los demanda, con la finalidad de aumentar sus ventas; por ejemplo, a través Portales Marketplace ${ }^{17}$, unas empresas demandan productos y otras los ofertan. Otro ejemplo de B2B, son las empresas que ofrecen contenidos web a través de redes sociales; Entre las ventajas que ofrece el B2B, están el ahorro de tiempo y costes, existe una mayor personalización por cliente; inconvenientes, presenta más dificultades a la hora de fidelizar al cliente.

- Transacciones entre empresa y consumidor ("Business-to-Consumer", "B2C"). Se trata de un modelo de negocio en el cual una empresa vende sus bienes y servicios al consumidor final. Puede darse el caso de que la venta o prestación se realice mediante servicios en línea o bien, a través de plataformas. Este modelo, es el más utilizado por los usuarios de internet, los canales que más se utilizan para realizar las transacciones son: emails de marketing, las redes sociales, los blogs, canales como YouTube, o plataformas como Amazon.

- Transacciones de consumidor a consumidor ("Consumer-to-Consumer", "C2C"): En este caso existe una empresa que actúa de intermediaria entre dos clientes. se establece una relación comercial donde la empresa tiene como finalidad aportar el espacio Marketplace, para facilitar el intercambio de productos entre dos consumidores finales; eBay o Wallapop son claros ejemplos de herramientas Consumer to Consumer.

- Transacciones entre la administración y consumidores ("Administration-to-Consumer", "A2C"). Esta modalidad es empleada para realizar trámites como el pago de sanciones.

- Transacciones entre las empresas y la administración ("Business-to-Administration", "B2A"). Es la relación que se establece entre la empresa y la administración sobre negocios relacionados con portales de transparencia para los Entes Públicos.

- Transacciones entre empresas y administraciones públicas ("Business-to-Government", "B2G"). Es el comercio donde las empresas especializadas en Proyectos de Ingeniería, Sistemas, Marketing, Servicios o asesorías brindan a los Gobiernos sus servicios de fabricación de equipos tecnológicos, Hardware, robótica etc.

- Transacción de consumidor a empresa ("Consumer-to-Business", "C2B"). Este tipo de transacción es muy similar al modelo B2C con la única diferencia de que el consumidor genera un valor a la empresa como intermediario, vendiendo sus servicios por ejemplo como influencer recomendando un producto de la empresa de la cual recibe un pago.

- Transacciones entre la Administración y las empresas ("Administration-to-Business", "A2B"). Esta modalidad, es la que ofrece la administración para la realización de trámites de pago con las empresas son transacciones donde se efectúan auditorias, certificaciones de calidad, denominaciones de origen promoción al exterior etc.

55. Para finalizar, una vez vistos los distintos modelos que se emplean en las transacciones de la economía digital, es necesaria destacar que los sistemas fiscales que se aplican a los modelos descritos anteriormente poseen puntos débiles que favorecen la erosión de ingresos para las arcas públicas de los Estados, y que se analizarán en el presente documento.

\footnotetext{
${ }^{17}$ El Portal Marketplace se puede definir como un local digital para hacer compras: dicho portar puede contener productos variados, o bien destinarse a un segmento especifico. Un Portal Marketplace está estructurado en: la plataforma, que sirve de puente para realizar las transacciones; El vendedor, que como asociado ofrece los productos previamente ordenados. El cliente, que es el destinatario final del producto.
} 


\section{Desafíos que plantea la economía digital en la fiscalidad internacional}

\section{La economía digital y su problemática}

56. Con el auge de las tecnologías de la información, el mercado digital y lo nuevos modelos de negocio, descritos anteriormente, aparecen nuevos desafíos para la economía digital que dejan en evidencia los sistemas tributarios tradicionales de las diferentes jurisdicciones internacionales, que se traducen en pérdidas de recaudación para sus arcas. Esta diversificación tributaria es aprovechada por las distintas compañías internacionales para planificar su fiscalidad en beneficio propio.

57. Conscientes de este problema distintas organizaciones internacionales como el G-20, o la Organización para la Cooperación y Desarrollos Económicos (OCDE), establecen medidas para evitar el traslado de beneficios a jurisdicciones de baja o nula tributación evitando la erosión y evasión fiscal. Es en julio de 2013, cuando se publica el «Plan de acción contra la erosión de la base imponible y traslado de beneficios (por sus siglas BEPS». Este plan está integrado por 15 acciones de las cuales, la primera de ellas se titula «Retos de la economía digital para la imposición». La Acción 1 del plan BEPS, va dirigida a abordar los retos y desafíos de la economía digital y su imposición; una economía digital en constante expansión, donde las transacciones están aumentando de forma exponencial, a la vez que también aumenta el fraude fiscal en este tipo de economía.

58. La economía digital presenta características muy distintas en relación a su fiscalidad, aunque no difiere mucho a la de la economía tradicional; la principal, la encontramos en la forma de realizar las transacciones, ya que la economía digital utiliza las nuevas tecnologías de la información y comunicación como Internet, que ha propiciado un aumento importante del comercio online durante las últimas décadas a través de plataformas como Google, Apple, YouTube, Amazon, Netflix entre otras.

59. Una de las principales dificultades de la economía digital aparece cuando las grandes multinacionales utilizan las tecnologías para eludir el pago de impuestos; es importante destacar la forma de actuar que tienen este tipo de macroempresas, que utilizan una estrategia muy similar, que consiste en instalar filiales en diferentes jurisdicciones o países con la finalidad de reducir la base imponible en el momento de tributar; generalmente los países en los que suelen establecer dichas sedes, suelen ser considerados "paraísos fiscales" o de baja tributación. En este sentido desde nuestra perspectiva, creemos que es necesario destacar que la economía digital no solo incluye la venta de bienes y servicios, (actividad que se conoce con el nombre de e-commerce), sino que, además, suele desarrollar otras actividades de intermediación, basadas en actividades que facilitan el contacto a sus usuarios para de este modo facilitarles las compras y las ventas. Este tipo de organizaciones empresariales suelen ubicarse en Estados con una elevada seguridad jurídica en cuanto a la protección de datos se refiere. Por lo tanto, podemos considerar que este tipo de organizaciones buscan en su modo operandi obtener una gran opacidad que dificulte la obtención de información sobre sus rentas de cara a tributar por ellas.

60. Por otra parte, es evidente que este tipo de comportamientos al uso, causan una gran preocupación entre los Estados, lo que ha generado el establecimiento de medidas para combatir el fraude y la elusión fiscal en el mercado de las transacciones digitales. Ante esta disyuntiva, el 5 de junio de 2021 los miembros del G-7 se reúnen en Londres ${ }^{18}$, para acordar distintas medidas que supondrán un antes y un después en la forma de tributar las rentas digitales. En este sentido se prevé establecer un tipo impositivo mínimo del 15\% del IS en el lugar o Estado donde se obtengan los beneficios, para luchar contra el fraude y la evasión fiscal. Esta medida supone que empresas como Amazon, Google o Facebook, no puedan tributar por sus operaciones realizadas en los territorios donde obtienen beneficios en condicio-

${ }^{18}$ G-7 Finance Ministers Agree Hostorical Global Tax Agreement (2021) 05 de junio. Recuperado en: https://www.g7uk. org/g7-finance-ministers-agree-historic-global-tax-agreement/ 
nes más ventajosas que las empresas con presencia física o establecimiento permanente en esos mismos territorios. La media sería ratificada en la reunión del G-20 celebrada en julio del mismo año.

61. Por otra parte, con la acción 1 del Plan BEPS, también se pretende ofrecer una solución al problema que surge en la tributación de las rentas procedentes del comercio digital, que no solo daña a los Estados donde se deja de tributar lo que realmente debería tributarse, sino que, además, produce un beneficio "ilícito" para este tipo de empresas organizadas. A pesar de todo, para autores como JIMÉNEZ VARGAS ${ }^{19}$ :

«La implementación de dichas medidas no es fácil, ya que dicho proyecto plantea algunos problemas de interacción entre los Estados por su carácter global»

62. En el caso de Europa, gracias al Plan BEPS, a partir de 2017, comienzan a desarrollarse numerosas iniciativas que desembocarán en dos proyectos; por un lado, se establece un marco de imposición directa que permita a los Estados miembros gravar los beneficios que se generen en su territorio por parte de empresas con presencia digital; por otro lado, se establece un régimen transitorio que hará gravar con un 3\% los ingresos generados por este tipo de actividades digitales, en concepto publicidad e intermediación de las plataformas digitales. Según JIMÉNEZ VARGAS:

«Se deben buscar mecanismos flexibles sin tener en cuenta una eventual incidencia de estos sobre la aparición de desigualdades fiscales entre Estados que podrían condicionar las decisiones de las multinacionales en relación a la tributación de sus rentas».

63. En este sentido, no son pocas las ocasiones en que la Unión Europea a través, del Consejo, ha destacado la importancia de establecer determinadas estrategias fiscales para establecer un Mercado Único Digital. Para ello, ha instado a los Estados miembros a agilizar la aplicación de mecanismos donde se incluya la supresión de barreras que, a fecha de hoy, aún siguen obstaculizando la libre circulación de bienes y servicios en línea; asimismo, el Consejo de Europa, insta a poner fin a la discriminación injustificada por motivos de localización geográfica. Este hecho queda consensuado con la aprobación del Reglamento 2018/302 del Parlamento Europeo «sobre medidas destinadas a impedir el bloqueo geográfico injustificado y otras formas de discriminación por razón de la nacionalidad, del lugar de residencia o del lugar de establecimiento de los clientes en el mercado interior». Paralelamente se modificarán el Reglamentos 2017/2394/UE, «sobre la cooperación en materia de protección de los consumidores» y la Directiva 2009/22/CE, «relativa a las acciones de cesación en materia de protección de los intereses de los consumidores».

64. Continuando con este epígrafe, la fiscalidad de la economía digital plantea otros desafíos que afectan tanto a los impuestos directos como indirectos; los criterios de fijación y calificación de los ingresos o rentas procedentes de este modelo de negocio suponen nuevos retos a la hora de calificar las rentas obtenidas. En este caso, se debe tratar la fiscalidad dependiendo si nos encontramos ante la venta o cesión de un determinado bien que no presenta internamente problema alguno, o bien, si se trata de una renta internacional, donde sí se nos puede plantear un problema cuando dicha renta puede estar sujeta a una distinta calificación dependiendo del Estado en el cual se genere.

65. En este sentido, pensamos que el problema se nos puede plantear cuando, por un lado, tratamos bienes o servicios prestados a través de la red, o bien, cuando los bienes o servicios se adquieren a través de la misma red. Por ejemplo, en el primero de los casos, la recaudación del Impuesto del Valor Agregado (IVA) se puede ver afectada en el comercio transfronterizo de bienes activos intangibles y servicios particularmente cuando los productos son adquiridos por usuarios finales en el extranjero,

${ }^{19}$ Vid. P. J. Jiménez VARgas (2018) "El nuevo convenio multilateral: Un paso a delante de la OCDE en la armonización fiscal en contra de la evasión y la elusión fiscal”. Quincena fiscal núm.19 Editorial Aranzadi Thomson Reuters, págs.19-46. 
mediante transacciones B2C (de empresa a consumidor). En el segundo de los casos, hablamos de contratación de bienes materiales que físicamente no presenta problemas, pero estaríamos hablando de una imposición directa, bien a través de Impuesto de Sociedades, o bien, a través de Impuesto de la Renta de los No Residentes, dependiendo de si se es persona física o jurídica. Es evidente que los problemas de calificación se dan más en el primero de los supuestos fundamentalmente porque se utiliza la vía telemática para transportar las mercancías o bienes desde el proveedor al cliente final.

66. En el caso de la economía digital, debemos destacar la importancia que tienen los bienes intangibles altamente especializados como son las marcas, algoritmos "Know how" intangibles debido a su alto valor y su elevada corporalidad pueden ser asignados y trasladados a jurisdicciones de baja o nula tributación, con lo que estaríamos posiblemente ante una conducta ilícita de evasión fiscal. De la misma forma, cuando tratamos con bienes intangibles altamente especializados nos encontramos con dificultados a la hora de establecer comparables suficientes que determinen en valor real de mercado. Esta circunstancia permite que los grandes grupos económicos establezcan los valores para dichas transacciones, es decir, entre compañías (intercompany), lo que suscita la posibilidad de erosionar la base imponible de sus rentas trasladando sus beneficios a jurisdicciones con una tarifa fiscal más favorable.

67. Esta erosión, también se traslada al ámbito de la economía digital fundamentalmente por la inexistencia de un espacio físico o establecimiento permanente, lo que permite a las empresas que operan digitalmente, la posibilidad de eludir la fiscalidad de aquellos países en donde operan, y trasladarla a aquellos cuya tributación le sea más favorable. Por otro lado, las empresas digitales adoptan características diferentes a las tradicionales, en relación a la forma de crear valor, por su actividad a distancia, por la contribución de los usuarios finales en dicha creación, y por la importancia de los activos intangibles, así como la tendencia a un mercado donde el que triunfa se arraigará con una fuerte presencia en las redes. Para LÓPEZ LABORDA ${ }^{21}$ :

«Un escenario como este ha facilitado la realización de estrategias de planificación fiscal agresiva porparte de empresas multinacionales. Estas hanvisto una oportunidad de situar los beneficios del grupoen jurisdicciones de baja o nula tributación o en soberanías con tributaciones de conveniencia, aprovechando, además, las crecientes dificultades de aplicación del principio de valoración de transacciones en plena competencia».

68. A las anteriores circunstancias, que ayudan a erosionar la base imponible del tributo sobre la renta, debemos añadir los convenios sobre doble imposición (CDI) que suscriben los Estados, que suelen otorgar a este tipo de multinacionales, determinados beneficios económico-fiscales, que facilitan aún más, la posibilidad de llevar a cabo una política fiscal agresiva. Pongamos como ejemplo, un Grupo Multinacional (GM), que tiene su sede matriz en un Estado (A); esta multinacional que presta sus servicios de publicidad a través de la red, posee una filial en un Estado (B) donde existe una tributación más favorable; señalar que entre el Estado A y B existe un convenio sobre doble imposición suscrito, que genera determinados beneficios fiscales.

69. Por otra parte, desde la filial situada en el Estado (B) se realizan ventas publicitarias a un tercer Estado (C). Ante la simulación, se nos plantea la siguiente realidad: primero, en tanto que la multinacional no tenga presencia física en el país (C) sus rentas no serán objeto de tributación en dicho país; segundo, la multinacional al tener una filial (B) situada en un país con tributación más favorable

\footnotetext{
${ }^{20}$ El know-how hace referencia al "Saber hacer", es decir, a la forma en la que la empresa hace las cosas, en la que emplea esos recursos para conseguir la producción, y dentro de la forma de hacer, a la forma ventajosa y diferente al resto que tiene la empresa de realizar sus actividades.

${ }^{21}$ Vid. J. López LaboRda (2020) "Retos a los que se enfrenta la fiscalidad de las multinacionales: las propuestas de la $O C D E ”$. Revista de economía Información Comercial Española, ICE, núm. 917 pág.12. Ministerio de Economía, Industria y Competitividad.
} 
ahorrará a la hora de tributar por minorar la base imponible del impuesto correspondiente; tercero, la multinacional podrá optar por trasladar dividendos del país (B) a (A), o bien, obtener los beneficios que se describen en el convenio suscrito y que podría pasar por una disminución de la carga impositiva o, por una exención o deducción sobre ésta. Por lo tanto, del ejemplo expuesto podemos extraer que, en el país (C), en el que se lleva a cabo la venta de publicidad y donde el servicio es apreciado o consumido, las ventas no estarían sujetas a imposición, por lo tanto, estaríamos en presencia de una realidad donde a través de la economía digital, se erosiona la base imponible de una jurisdicción en favor de otra con la tarifa impositiva más favorable.

70. Como señala la OCDE en el documento "Lucha contra la erosión de la base fiscal y la transferencia de beneficios" (2013), parte, de la problemática que se produce en relación con la tributación digital se refiere a la lenta evolución de determinados Estados en relación con su desarrollo normativo. Este hecho, ha provocado supuestos doble no imposición, donde la Organización intergubernamental se ha pronunciado señalando que:

«Las normas nacionales que regulan la tributación internacional y las normas internacionalmente acordadas se refieren todavía a un entorno económico caracterizado por un bajo nivel de integración económica entre los países, mientras que el entorno actualde los contribuyentes a escala mundial se caracteriza por una importancia cada vez mayorde la propiedad intelectual como factor determinante del valor y por una evoluciónconstante de las tecnologías de la información y comunicación».

71. Por su parte, la Unión Europea a través de directivas relacionadas con la materia señalada, ha indicado lo siguiente ${ }^{22}$ :

«Las actuales normas sobre el impuesto sobre sociedades se basan en el principio de que se debe tributar por los beneficios alli donde se genera el valor. Pero estas normas fueron concebidas en su mayoría a principios del siglo XX para empresas tradicionales con una presencia física y definen lo que genera el hecho imponible en un pais («dónde tributar») y qué parte de la renta de las sociedades se asigna a un país ("cuánto tributar») basándose en gran medida en que tengan presencia física en dicho país y sin reflejar el valor creado por la participación del usuario en esa jurisdicción».

72. Esto significa que las entidades que no tienen residencia fiscal en un determinado país, sí tienen la obligación de tributar en dicho país, si su presencia en el mismo esta asimilada a un establecimiento permanente.

«Sin embargo, tales normas no pueden aprehender el alcance mundial de las actividades digitales cuando la presencia fisica deja de ser un requisito para poder prestar servicios digitales. Por lo tanto, se necesitan nuevos indicadores de una presencia económica importante para determinar los derechos impositivos en relación con los nuevos modelos empresariales digitalizados».

73. Finalmente, otras dificultades que pueden generarse en el comercio electrónico las encontramos en la localización de las actividades comerciales telemáticas, y en la cuantificación de las transacciones; en el primer caso, las dificultades se plantean por motivos de geolocalización donde se pueden producirse conflictos entre la localización del hecho imponible y el sujeto pasivo. En el segundo caso, las dificultades aparecen, porque tratamos con bienes intangibles que generan rentas cuya calificación es difícil obtener, al tratarse de operaciones vinculadas. A ello, debemos unir las dificultades de control de las transacciones telemáticas, tanto en el rastreo de los medios de pago que son múltiples, como en las dificultades para conocer con exactitud el número de operaciones y transacciones realizadas.

${ }^{22}$ Directiva 2018/0072 del Consejo de Europa de 23 de marzo. Recuperado en: https://eur-lex.europa.eu/legal-content/ES/ TXT/aHTML/?uri=CELEX:52018PC0147\&from=ES 


\section{El beneficiario efectivo en la fiscalidad de las rentas internacionales}

\section{A. Introducción}

74. Hoy en día el concepto beneficiario efectivo (en adelante BE) es un elemento clave en la aplicación de los acuerdos firmados entre Estados para evitar la doble tributación. Estos acuerdos o convenios para evitar la doble imposición (CDI) se aplican en particular, en lo que respecta a la distribución de la potestad tributaria sobre dividendos, intereses y regalías. Por otra parte, a pesar de la introducción de este concepto en modelos sobre las rentas y el patrimonio como el de la Organización para la Cooperación y el Desarrollo Económicos, (MCOCDE) de 1977, o el de la Organización de las Naciones Unidas, (ONU), aún persisten muchas dudas sobre su verdadero alcance y repercusión. Como veremos a continuación, la falta de una definición exhaustiva del concepto "beneficiario", ha provocado la falta de consenso a la hora de interpretarlo en las legislaciones nacionales de cada país. La realidad es que la forma de interpretar el termino beneficiario es independiente y autónoma de cada jurisdicción, sin que lamentablemente la jurisprudencia y la doctrina internacional hayan llegado a un concepto consensuado.

75. Actualmente los CDI's celebrados bajo el Modelo de Convenio de la OCDE, utilizan el esquema de reparto y distribución de competencias entre los Estrados contratantes, en relación a las rentas obtenidas por un residente en un Estado distinto al de su residencia; en términos generales, el criterio establecido a la hora de someter las rentas es el siguiente:

«Los beneficios obtenidos por una entidad residente en un Estado contratante sólo pueden ser sometidos a imposición en aquel, salvo que existiera un establecimiento permanente en el otro Estado contratante, en cuyo caso, éste último Estado podrá gravar las rentas que resulten atribuibles a dicho Establecimiento permanente».

76. Del mismo modo existe un criterio específico para tratamiento de determinadas rentas, que pasan por una tributación exclusiva ya sea en el Estado de la fuente, ya sea en el Estado de residencia, o bien sea de forma compartida, en cuyo caso el Estado de residencia suele establecer unos límites en la tributación del país de la fuente, estableciéndose de este modo, un mecanismo para evitar la doble imposición internacional. Con respecto a los dividendos, intereses o regalías, generalmente los criterios que se adoptan por los Estados suscriptores de CDI's, pasan por gravar las rentas en el Estado de residencia y en el Estado de la fuente; en el caso del Estado de la fuente, éste deberá someter dichas rentas hasta unos límites; es aquí, cuando la figura del beneficiario efectivo adquiere relevancia, ya que los límites que establece el Estado de la fuente, solo operaran en la medida que las rentas sean percibidas por un sujeto que resida en el otro Estado contratante, que sea considerado beneficiario efectivo. De este modo, las rentas obtenidas por una persona residente en otro Estado, harán que ésta adquiera la condición de beneficiario efectivo, por lo tanto, no resultaran aplicables las limitaciones descritas anteriormente.

77. Por último, el concepto de un beneficiario efectivo se configura como un mecanismo cuya finalidad además de determinar a quién le corresponde tributar determinadas rentas, sirve para combatir el "abuso de los convenios" o, el "Treaty shopping", que consiste en el uso de los convenios por parte de sujetos no residentes de un Estado para obtener los beneficios que un convenio suscrito por dicho Estado concede a sus residentes; por ejemplo, obtener una tasa impositiva inferior a la que se tendría si no se hubiera utilizado el CDI, o, eliminar total o parcialmente la imposición bajo operaciones de triangulación entre entidades situadas en distintas jurisdicciones. La OCDE, ante esta situación, introduce algunos límites en su Modelo de Convenio, con la finalidad de evitar que el beneficiario efectivo del CDI, sea un sujeto no residente, a su vez recomienda a los Estados introducir el concepto beneficiario efectivo en sus convenios tributarios. 


\section{B. Concepto y Origen}

78. La incorporación del término beneficiario efectivo en el MCOCDE se produce con la finalidad de clarificar si el Estado de la fuente tiene la obligación o no a renunciar al derecho de cobrar tributos a un residente en otro Estado, por sus beneficios económicos obtenidos, cuando existe entre las jurisdicciones un convenio suscrito. El concepto beneficiario efectivo no se usa en su sentido técnico más riguroso, sino que se debe interpretar en un contexto donde predomina la voluntad, y la intención de los Estados implicados en el convenio para evitar la doble imposición fiscal, a la vez que previenen la evasión y elusión fiscal. A la hora de establecer una definición la RAE (Real Academia Española), define el concepto "beneficiario" como "persona que recibe una prestación o bien resulta favorecida por algo". A nivel internacional, organismos como el Grupo de Acción Financiera Internacional (GAFI) en su Guía sobre Transparencia y Beneficiario Final, no utiliza el término "efectivo", pero lo define de la siguiente manera: Según $\mathrm{GAFI}^{23}$ :

«Pueden ser considerados como beneficiarios finales quienes finalmente poseen/controlan a la persona jurídica, ya sea a través de una participación mayoritaria, a través de posiciones mantenidas en persona jurídica o por otros medios como: La(s) persona(s) fisica(s) que posean directa o indirectamente un porcentaje mínimo de participación en la persona jurídica (enfoque de umbral). Por ejemplo, la Recomendación 24 permite la determinación de los accionistas con participación controladora de una sociedad mercantil en base a un umbral (por ejemplo, cualquier persona que sea titular de más de un determinado porcentaje de la sociedad mercantil, como por ejemplo el 25\%)》.

79. Como podemos observar, esta definición engloba a personas físicas (no jurídicas), que poseen y obtienen beneficios de capital o patrimonio de personas jurídicas y, de aquellas otras que ejercen un control efectivo sobre dicha persona jurídica, con independencia de que ocupen o no cargos formales. Por su parte, el Foro Global de Transparencia y la OCDE, y el Banco Interamericano de Desarrollo, definen al beneficiario final como $^{24}$ :

«El concepto beneficiario final se refiere a las personas naturales que son los verdaderos dueños o controlantes o quienes se benefician económicamente de un vehículo jurídico, como una sociedad mercantil, un fideicomiso, una fundación, etc.».

80. Con respecto a la interpretación del concepto de Beneficiario efectivo, en el ámbito internacional surgen distintas posiciones, a saber; existe una corriente que sostiene que el concepto debe ser interpretado con la normativa interna de cada Estado, siempre que no haya una definición expresa en acuerdo, tratado o CDI suscrito. Tal consideración viene recogida tal cual, en el artículo 3.2 del MCOCDE:

«Para la aplicación del Convenio por un Estado contratante en un momento determinado, cualquier término o expresión no definida en el mismo tendrá, a menos que de su contexto se infiera una interpretación diferente, el significado que en ese momento le atribuya la legislación de ese Estado relativa a los impuestos que son objeto del Convenio, prevaleciendo el significado atribuido por esa legislación fiscal sobre el que resultaría de otras Leyes de ese Estado».

81. Por lo tanto, no se puede aplicar el principio de beneficiario efectivo, si el Convenio no lo prevé de forma expresa. Así se establece en ST del Tribunal Supremo de 23 de septiembre de 2020.

${ }^{23}$ El Grupo de Acción Financiera Internacional (GAFI) es un organismo intergubernamental independiente, que desarrolla y promueve políticas para proteger el sistema financiero mundial contra el lavado de activos, la financiación del terrorismo y la financiación de la proliferación de armas de destrucción masiva. Se reconocen las Recomendaciones del GAFI como el estándar global anti-lavado de activos (ALA) y contra el financiamiento del terrorismo (CFT). Recuperado en: file:///C:/Users/ serra/Downloads/Guia_Transparencia_Beneficiario_Final\%20(1).pdf

${ }^{24}$ Foro Global sobre Transparencia e Intercambio de Información con Fines Fiscales Banco Interamericano de Desarrollo, y la OCDE (2019) "Manual sobre beneficiarios fiscales”, pág.3. Recuperado en: https://publications.iadb.org/es/manual-sobrebeneficiarios-finales 
En este caso, el Tribunal Supremo insta a las partes a aclarar los límites objetivos y temporales de la conocida interpretación dinámica de los CDI's suscritos por España, con el fundamento del Modelo de Convenio de la OCDE. El tribunal alude al Convenio de doble imposición entre España y Suiza; a pesar que en este CDI, no se prevé el concepto de "beneficiario efectivo" en su artículo 12, al tratarse de un Convenio anterior al reconocimiento por la OCDE de la figura beneficiario.

82. En la Sentencia el alto Tribunal se pronunció de la siguiente manera:

«Se aplica esta figura de acuerdo con los Comentarios al Modelo de Convenio de la OCDE (elaborados en una fecha posterior a la formalización inicial del Convenio), a pesar de que en las modificaciones posteriores del citado CDI no se introdujo el beneficiario efectivo en el articulo 12 (relativo a los cánones), y sí en otros preceptos (artículos 10 y 11) para otros conceptos como dividendos o intereses ${ }^{25}$.

83. Del mismo modo, tras analizar la posibilidad de aplicación del tipo de retención previsto en el mismo Convenio hispano-suizo, para prevenir la doble imposición, (en este caso los cánones satisfechos por una sociedad española a una entidad suiza) el Tribunal Supremo determina que ésta última no es la beneficiaria de dichos cánones. Finalmente, mediante Recurso de Casación 1996/2019, ratifica la Sentencia de la Audiencia Nacional donde se concluye que $^{26}$ :

«A pesar que la entidad perceptora de los cánones era residente en Suiza no se puede considerar de aplicación el convenio hispano-suizo para evitar la doble imposición en materia de impuestos que establecía una retención de del $5 \%$ al entender que no es beneficiario efectivo».

«La posición más razonable, así lo entiende la mejor doctrina, es entender que esta figura es aplicable y debe tenerse en cuenta al interpretar el Convenio, pues estos deben interpretarse, en la medida de lo posible, de conformidad con el espiritu de los Comentarios de la OCDE».

84. En el mismo contexto, se plantean problemas a nivel transfronterizo, por ejemplo, si deben, o no aplicarse los beneficios de un IIC (Instrumento de Inversión Colectiva), ya que como establece el propio MCOCDE, existen países que con independencia de que sea una "persona" y "residente".

«Puede considerarse beneficiario efectivo de las rentas que percibe. Dado que un IIC tal como se define, en los propios Comentarios del MCOCDE debe tener un número importante de titulares, una cartera de valores diversificada y estar sujeto a la normativa para la protección de los inversores vigente en el país en el que se haya constituido, tal IIC, por lo tanto, existirán beneficiarios».

85. En este contexto las disposiciones de los párrafos $6.17,6.21,6.26$ y 6.32 de los comentarios al artículo 1, del MCOCDE, consideran al Instrumento de Inversión Colectiva a efectos de aplicación del convenio a la renta que se percibe, como residentes beneficiarios efectivos de dichas rentas a diferentes grupos. Esta postura, ha sido rebatida fuertemente por autores con VOGEL, que considera que el término "beneficiario efectivo" debería ser internacional, y aplicarse por igual en todos los convenios y tratados internacionales, ya que como insiste el autor, los sistemas nacionales no ofrecen una definición precisa del mismo. De igual forma, tampoco lo hace el Modelo de Convenio de la OCDE, aunque sí, se limita en los comentarios al artículo 12 apartado $1^{\circ}$, a establecer la siguiente interpretación ${ }^{27}$.

«El concepto "beneficiario efectivo" no se utiliza en su "sentido técnico más estricto”, sino que debe más bien interpretarse en su contexto y a la luz de los objetivos e intenciones del Convenio, incluyendo la voluntad de evitar la doble imposición y de prevenir la evasión y la elusión fiscales».

${ }^{25}$ STS 3062/2020 Sala de lo Contencioso 23/09/2020. Recuperado en: https://www.poderjudicial.es/search/TS/openCDoc ument/47c54a4d73e1a19676437e91cf620c6570e9d580b86c5512

${ }^{26}$ SAN 5203/2018 Sala de lo contencioso 30/11/2018. Recuperado en: https://www.poderjudicial.es/search/TS/openCDocument/d6c3141dd81d8758655cf4715fc787b34aa8403b1a843aa3

${ }^{27}$ Modelo de Convenio Tributario sobre la Renta y el Patrimonio -OCDE - (2010) pág. 227. 
86. Por lo tanto, la interpretación que debe de hacerse del concepto beneficiario efectivo debe ser "autónoma", por cada uno de los Estados, para darle un sentido internacional; ante esta interpretación, cabe hacerse la pregunta de: ¿a quién se debe considerar beneficiario efectivo de una renta?; como hemos referido anteriormente, el propio MCOCDE diserta en las disposiciones de los comentarios al artículo 1, sobre quienes se pueden considerarse beneficiarios efectivos de las rentas procedentes de Instrumentos de Inversión Colectiva (IIC). Para autores como, $\mathrm{VOGEL}^{28}$, la cuestión del control es un factor determinante para establecer quien es el beneficiario efectivo de la renta final; según este autor, aunque el control es fundamental para determinar al beneficiario, no lo es necesariamente en beneficio de la persona que controla, y lo afirma diciendo que:

«Un fideicomisario con los poderes correspondientes también es un beneficiario final, el fiduciario, por supuesto, no ejerce sus poderes para su propio beneficio, sino en beneficio de los beneficiarios».

87. Por su parte, $\mathrm{BAKER}^{29}$, propone una "regla de oro" que consiste que en caso de que una receptora del ingreso entrara en proceso de liquidación y hubiese sido una mera fiduciaria, los ingresos percibidos podrían ser reclamados por el verdadero beneficiario efectivo y no estarían a disposición de los acreedores.

88. Del mismo modo si los ingresos pertenecieran a la entidad receptora que está en proceso de liquidación, los ingresos, sí estarían a disposición de los acreedores, y ella habría sido su beneficiario efectivo.

89. Desde nuestro punto de vista, no existe un beneficiario efectivo, sino un conjunto de relaciones donde participa todo aquel sujeto o persona ya sea "f́́sica" o "jurídica", a través, de un proceso de intercambio efectivo, de bienes, servicios o mercancías; por lo tanto, no existe un beneficiario final, ni un único beneficiario, ya que en una situación de intercambio, el beneficio se distribuye entre las partes que interactúan de forma recíproca con un fin común, que no es otro que obtener "beneficio propio"; es decir, tanto el que vende un producto financiero o de otra índole, como el que compra, así como el intermediario, lo hace con el mismo fin. Cosa distinta sería, determinar el tipo de beneficio y su cuantía; es aquí, donde juega un papel fundamental el poder en todas sus variantes: económico, social, político, que debería estar armonizado y en equilibro, para que el resultado final sea un conjunto de "beneficiarios satisfechos", dentro del proceso de intercambio; de lo contrario estaríamos ante abuso de poder, en toda regla, y ante un "beneficiario déspota" y posiblemente ante un fraude fiscal.

90. A continuación, nos disponemos a establecer cuáles son los posibles orígenes de la figura del beneficiario efectivo objeto de estudio en este epígrafe:

91. Para poder determinar los orígenes y establecer un punto de partida de la figura del "beneficiario efectivo", debemos remontarnos al Siglo XII en Reino Unido, en el momento de las Cruzadas, que es cuando surge una figura muy particular denominada "Trust"; la función de esta figura consistía en la tenencia de bienes y valores por parte de una persona interpuesta por un tercero, Los cruzados, en su ausencia necesitaban la confianza de una persona que cuidara de sus bienes cuando éstos se encontraban ausentes. Los Trust, podían ejercer plenos derechos sobre los bienes, y es en este contexto cuando surgen dos figuras asociadas entre sí: el legal ownership y el beneficial ownership; es decir, la propiedad legal y la propiedad real, para referirse a la persona responsable de la administración de estos bienes y a su propietario.

92. Hoy en día, saber quién es la persona física detrás de una figura contractual o estructura legal, es, un requisito fundamental dentro de los estándares de transparencia fiscal internacional. Por

\footnotetext{
${ }^{28}$ Vid. Klaus Vogel (1997) et al., Klaus Vogel on Double Taxation Conventions, págs...561-562.

${ }^{29}$ Vid. P. BAKer (1993) "Double Taxation Conventions", ob.cit., 10B, 15
} 
primera vez esta cuestión la podemos apreciar en la Ley de Finanzas (Reino Unido) de 1954, en su artículo 175, donde se señala que: «cualquier referencia a la propiedad se entenderá como referencia al beneficiario real». Por otra parte, el Tribunal Superior de Justicia del Reino Unido, a través del Caso 45 TC 112: Preservation Wood Ltd, anteriormente (Inspector de impuestos), enfatiza que el término beneficioso real (beneficial owner) se refiere a un tipo de propiedad donde no sé es, el propietario legal (legal owner), ya que este último lo es para fines de registro, y puede realizar actos sobre la propiedad como verdadero propietario.

93. En cuanto al reconocimiento institucional, será en 1977, cuando organizaciones internacionales como la OCDE introduzcan por primera vez el término "beneficiario", y lo hace en su MCOCDE, dentro de las disposiciones relativas a los dividendos, intereses y regalías. En un principio, no se estableció ninguna definición genérica, pero se registró como un tipo de condición o cualidad: (“...), pero si el beneficiario"), se declara en el apartado de ingresos mencionados anteriormente. En la actualidad, el MCOCDE de 2017, en su artículo 3, de las disposiciones generales muestra de forma resumida que: «para la aplicación del Convenio, cualquier término no definido en el mismo tendrá, el significado que en ese momento le atribuya la legislación de ese Estado relativa a los impuestos objeto del Convenio».

\section{La figura del beneficiario efectivo en el Modelo de Convenio de la OCDE, en el Ordenamiento Jurídico Europeo y en la Legislación Española}

94. La figura del beneficiario efectivo es un elemento clave para interpretar y aplicar determinados artículos de los convenios sobre doble imposición suscritos entre los Estados. Estos CDI's son celebrados en base al Modelo de Convenio de la OCDE, donde se establece un esquema para el reparto de la potestad tributaria entre los Estados en relación a las rentas obtenidas en uno de ellos, por un residente en otro Estado. La regla general del Modelo de convenio utiliza el criterio por el cual: «Los beneficios de una empresa de un Estado contratante solamente pueden someterse a imposición en ese Estado, a no ser que la empresa realice su actividad en el otro Estado contratante por medio de un establecimiento permanente situado en él. Si la empresa realiza su actividad de dicha manera, los beneficios imputables al establecimiento permanente de conformidad con las disposiciones del apartado 2 pueden someterse a imposición en ese otro Estado» ${ }^{30}$.

95. La OCDE estableció un comité de finanzas en 1956, de conformidad con el panorama general de las Naciones Unidas; más tarde, este comité paso a llamarse Comité de Asuntos Fiscales, dedicado a estudiar cuestiones relacionadas con la doble imposición internacional y otras cuestiones fiscales de naturaleza similar. En el año 1977 tras la revisión de los esquemas de la OCDE, se emite formalmente el nuevo "Modelo de Convenio para evitar la doble imposición a la renta y al patrimonio". En este modelo, los ingresos por dividendos, intereses y regalías se introducen en los artículos 10,11 y 12 respectivamente, para explicar el significado de las palabras "pagados a un residente" tal y como se recoge en dichos artículos; sin embargo, en ninguna parte de los citados artículos se define el significado de beneficiario efectivo, de igual modo que tampoco lo hacen los Comentarios al Modelo de Convenio. No obstante, creemos que el termino se interpreta de acuerdo con el objetivo del convenio, que no es otro que el evitar la doble imposición y prevenir la evasión y la elusión fiscal.

96. Como podemos ver en una primera aproximación, el término beneficiario "final" o "efectivo", se introduce en el Modelo de Convenio de la OCDE como un requisito subjetivo para que los residentes de un Estado parte, puedan beneficiarse de una tasa impositiva reducida relacionada con los ingresos recibidos en el país de origen. Si el objetivo principal de incluir el concepto de "beneficiario efectivo" en el Modelo de Convenio de la OCDE es, prevenir la elusión fiscal mediante el uso de los CDI's limitando las ventajas que el tratado otorga a quienes exclusivamente residen en el otro Estado

${ }^{30}$ Artículo 7, Modelo de Convenio Tributario sobre la Renta y el Patrimonio -OCDE - (2010) pág. 26. 
contratante; en la práctica, el Modelo de Convenio menciona al beneficiario efectivo de los pagos a los residentes de los Estados contratantes, lo que ha causado mucha controversia en el ámbito de la tributación internacional, siendo rebatido por la doctrina. No obstante, a día de hoy el concepto beneficiario efectivo no solo tiene un significado poco claro, sino que, además, parece haber creado una brecha importante entre las tendencias administrativas y jurisdiccionales. Por lo tanto, en este apartado nos centraremos en la evolución y estudio de las fuentes del soft law de los artículos 10, 11 y 12 del Modelo de Convenio OCDE.

97. En este contexto, los acuerdos que se recogen en la estructura del MCOCDE, están estrechamente relacionados con los comentarios que esta organización lleva a cabo sobre los mismos, siendo por consiguiente oportuno y necesario detectar los componentes comunes del concepto beneficiario efectivo de cada uno de los artículos mencionados. Como hemos comentado anteriormente, este concepto se introdujo en el Modelo de Convenio de la OCDE en 1977 como una enmienda del modelo anterior de 1963 que cubría únicamente la evasión fiscal. Por tanto, podemos reiterar que el motivo o los motivos de la introducción del término beneficiario, no están claros; de hecho, la redacción del modelo de 1963, no contenía disposición alguna que abordara el abuso de los convenios para evitar la doble tributación en relación a la evasión fiscal. En relación a la tributación entre Estados, la redacción original del modelo de $1977^{31}$ establecía lo siguiente:

Artículo 10 (dividendos): «Los dividendos pagados por una sociedad residente en un Estado contratante a un residente del otro Estado contratante pueden someterse a imposición en este otro Estado».

98. Sin embargo, dichos dividendos pueden someterse a imposición en el Estado contratante de donde la empresa que paga los dividendos es residente, y de acuerdo con la ley de ese Estado, pero el impuesto así cobrado no excederá del:

a) 5 por ciento del monto bruto de los dividendos si el perceptor es una empresa (excluida la sociedad) que posee directamente al menos el 25 por ciento del capital de la empresa que paga los dividendos;

b) en todos los demás casos, el 15 por ciento del importe bruto de los dividendos.

99. Las autoridades competentes de los Estados contratantes deberán de mutuo acuerdo determinar el modo de aplicación de esta limitación. Este párrafo no afectará la tributación de la empresa con respecto a de los beneficios con los que se pagan los dividendos. El término «dividendos», tal como se utiliza en este artículo, significa rentas de acciones, Acciones de «goce» o derechos de «goce», acciones de minería, acciones de fundadores u otros derechos, no siendo deudas, la participación en utilidades, así como ingresos de otros derechos corporativos asimilados a ingresos de acciones por la ley tributaria del Estado del cual la empresa que realiza la distribución es residente.

Artículo 11 (intereses): «Los intereses procedentes de un Estado contratante y pagados a un residente del otro Estado contratante pueden someterse a imposición en este otro Estado».

100. Sin embargo, dichos intereses pueden someterse a imposición en el Estado contratante en el que surge, y de acuerdo con la ley de ese Estado, pero el impuesto así cobrado no excederá del 10 por ciento del monto de los intereses. La competencia de las autoridades de los Estados contratantes establecerán de mutuo acuerdo el modo de aplicación de esta limitación.

101. El término «interés», tal como se utiliza en este artículo, significa ingresos de valores gubernamentales, bonos u obligaciones, estén o no garantizados por hipoteca y si tiene o no derecho a par-

\footnotetext{
${ }^{31}$ Recommendation of the Council OECD (1977) Legal Instruments concerning the Avoidance of Double Taxation. Recuperado en: https://legalinstruments.oecd.org/public/doc/405/405.en.pdf
} 
ticipar en las ganancias, y reclamaciones de deudas de todo tipo, así como todos los demás ingresos asimilados a ingresos de dinero prestado por la ley tributaria del Estado en el que se obtienen los ingresos.

Artículo 12 (regalías): «Las Regalías procedentes de un Estado contratante y pagadas a un residente del otro Estado contratante sólo puede someterse a imposición en ese otro Estado».

102. El término «regalías», tal como se utiliza en este artículo, significa los pagos de cualquier tipo recibidos como contraprestación por el uso de, o el derecho a usar, cualquier derecho de autor de obras literarias, artísticas o científicas, incluido el cinematográfico de películas, cualquier patente, marca, diseño o modelo, plan, fórmula secreta o proceso, o para el uso de, o el derecho de uso, industrial, comercial o equipo científico, o para información relativa a industrial, comercial o experiencia científica.

103. De la redacción original de 1977, podemos llegar a la conclusión de que para que el Estado de la fuente pueda limitar o eliminar la tributación sobre las rentas en la fuente, el perceptor debe de ser a la vez beneficiario efectivo de estas.

104. El 27 de noviembre de 1986 la OCDE, en su "Reporte sobre Sociedades Instrumentales o Conductoras" ${ }^{\prime 2}$ hace énfasis sobre los comentarios en relación a los convenios de doble imposición y el uso de empresas conductoras.

105. En el reporte, se establece que, en caso de que la sociedad intermedia no sea la beneficiaria efectiva, no se aplicarán en el Estado de la fuente los límites a la imposición real previstos en los artículos 10 a 12 del Modelo. Además, añade que esto será así cuando económicamente la reducción o eliminación de la tributación, beneficie a un sujeto que en principio no tiene derecho a la aplicación de un convenio, pero que interpone una sociedad conductora entre él y el pagador del rendimiento para lograr ese fin (párrafos 2.12, 2.8 y 1.4 de los comentarios a los artículos 10,11 y 12, respectivamente) 33. En 1986 el Comité de Asuntos Fiscales de la OCDE, no estableció nada novedoso respecto de los comentarios de años anteriores, pero en los comentarios de 1986 se plantea que:

«Una sociedad instrumental no puede ser considerada normalmente como beneficiario efectivo si, pese a ser el propietario de hecho a efectos prácticos, cuenta con poderes muy restringidos que le convierten, con respecto a la renta en cuestión, en un mero fiduciario o administrador que actúa por cuenta de las partes interesadas».

106. Es decir, si no puede disponer libremente del rendimiento porque, ya sea al constituirse o bien porque con posterioridad, se ha determinado que debe transferir el rendimiento a un tercero, la OCDE plantea que el perceptor de los rendimientos es un "mero fiduciario" de un tercero domiciliado en un tercer país. Para BAKER. «la esencia de este Comentario es para explicar que la limitación de beneficiario efectivo tiene el propósito de excluir: (i) meros mandatarios y agentes quiénes no son tratados como los propietarios de la renta en el País de residencia, y (ii) cualquier otro instrumento, (conducto) que, aun siendo el propietario formal de la renta, tiene poderes muy limitados sobre la misma convirtiéndolo en un mero fiduciario, o administrador, actuando en nombre de su propietario» ${ }^{34}$.

107. Continuando y de forma cronológica, en 1995 se producen cambios en la redacción de los artículos 10, 11 y 12 del Modelo de Convenio de la OCDE donde se modifican los requisitos para obtener los beneficios establecidos en los convenios. La modificación consiste en sustituir la expresión

\footnotetext{
${ }^{32}$ Convenio de doble imposición y uso de empresas conductoras (adoptados por el consejo de la OCDE el 27 de noviembre de 1986) Recuperado en: https://read.oecd-ilibrary.org/taxation/model-tax-convention-on-income-and-on-capital-2014-fullversion/r-6-double-taxation-conventions-and-the-use-of-conduit-companies_9789264239081-99-en\#page1

${ }^{33}$ Commentaries on the articles of the Model Tax Convention (1986) pág.221. Recuperado en: https://www.oecd.org/berlin/ publikationen/43324465.pdf

${ }^{34}$ Vid. P. BAKER “Comentarios al Modelo de Convenio OCDE”, Párrafos 10.b, 10.4
} 
"si el perceptor de los dividendos o intereses es el beneficiario efectivo", por la expresión, "si el beneficiario efectivo de los dividendos o intereses es residente del otro Estado contratante". En el año 2003, se completan los comentarios anteriores; en concreto en el nuevo comentario al artículo $10^{35}$ (dividendos) en su párrafo 12 establece que: «el término "beneficiario final" no se utiliza en un sentido técnico estricto, más bien, debe entenderse en su contexto y a la luz del objeto y los propósitos de la Convención, incluida la prevención de la doble imposición y la prevención de la evasión y elusión». En este caso se agrega el concepto elusión fiscal.

108. Por su parte en el párrafo 12.1, se establece que: «cuando un residente de un Estado contratante actúe en calidad de agente o designado, será incompatible con el objeto y el propósito de la Convención que el Estado de origen otorgue en forma de reparación o exención, simplemente, por tener la condición de perceptor inmediato de la renta como residente del otro Estado contratante».

109. Por lo tanto, en la nueva modificación, se añade que, si el contribuyente actúa en calidad de agente, el Estado de la fuente no otorgará el beneficio contemplado; además, se establece que en estos casos no deben aplicarse los beneficios establecidos en los convenios, puesto que el perceptor de los rendimientos no quedaría sujeto al impuesto del Estado de su residencia, por no ser beneficiario efectivo de los mismos. Esta circunstancia evita un problema de doble imposición ya que el perceptor no será considerado propietario de la renta a efectos fiscales en el país de residencia. En este contexto, el Comité de Asuntos Fiscales de la OCDE, señala que una sociedad instrumental no puede ser, considerada como el beneficiario efectivo si, a pesar de ser formalmente la dueña, tiene poderes tan limitados que la hacen, en relación al rendimiento en cuestión, una mera fiduciaria o administradora que actúa por cuenta de las partes interesadas.

110. 2003, será el último año donde se establezcan modificaciones relativas el termino beneficiario efectivo, ya que, en los comentarios de los años 2005, 2008 y 2010 apenas traen consigo innovación alguna al respecto. Como hemos visto anteriormente el Modelo de Convenio de la OCDE utiliza el termino Beneficiario efectivo en los artículos 10 (sobre dividendos), 11, (sobre intereses) y a partir de 1977 en el artículo 12 sobre regalías o cánones. Las modificaciones que se producen respecto a las anteriores versiones son las siguientes ${ }^{36}$ :

Respecto a los dividendos del artículo 10 en el apartado 2: «dichos dividendos pueden someterse también a imposición en el Estado contratante en que resida la sociedad que paga los dividendos y según la legislación de ese Estado; pero, si el beneficiario efectivo de los dividendos es un residente del otro Estado contratante», el impuesto así exigido no podrá exceder del:

a) 5 por 100 del importe bruto de los dividendos si el beneficiario efectivo es una sociedad (excluidas las sociedades de personas -partnerships-) que posea directamente al menos el 25 por 100 del capital de la sociedad que paga los dividendos;

b) 15 por 100 del importe bruto de los dividendos en los demás casos.

111. Por lo tanto, respecto a la versión anterior los dividendos por regla general recogida en el convenio es que la tributación sea compartida entre el Estado de la fuente, y el Estado de residencia del perceptor. En el caso del Estado de la fuente, la tributación se limita a gravar el rendimiento en base a la tasa máxima establecida en el convenio suscrito entre los Estados.

112. En cuanto a los intereses, (artículo 11 Modelo de Convenio) «dichos intereses pueden someterse también a imposición en el Estado contratante del que procedan y según la legislación de ese

\footnotetext{
${ }^{35}$ Commentaries on the articles of the Model tax Convention (Condensed Version) OECD 2010, pág187. Recuperado en: https://www.oecd.org/berlin/publikationen/43324465.pdf

${ }^{36}$ Modelo de Convenio Tributario sobre la Renta y sobre el Patrimonio: versión abreviada 2010 (OCDE). Recuperado en: https://read.oecd-ilibrary.org/taxation/modelo-de-convenio-tributario-sobre-la-renta-y-sobre-el-patrimonio-version-abreviada_ 9789264184473-es\#page2.
} 
Estado, pero si el beneficiario efectivo de los intereses es un residente del otro Estado contratante, el impuesto así exigido no podrá exceder del 10 por 100 del importe bruto de los intereses. Las autoridades competentes de los Estados contratantes establecerán de mutuo acuerdo las modalidades de aplicación de ese límite».

113. Al igual que sucede con los dividendos, la tributación quedará compartida entre el Estado de la fuente y el Estado de residencia, en la medida de que este último será considerado beneficiario efectivo. Por lo tanto, el impuesto sobre los intereses se limitará al Estado de la fuente y a su vez el Estado de residencia deberá establecer un método para deducir el impuesto pagado en el exterior. Por último, en cuanto a las regalías del artículo 12, el Estado facultado para gravar dichos rendimientos será el Estado de residencia. En este caso el Estado de la fuente debe excluirse de la imposición de estas regalías, siempre y cuando al igual que sucede con los dividendos e intereses, quien perciba el royalty sea el beneficiario efectivo de estos y que resida en otro Estado contratante.

114. Con respecto a las regalías, la situación difiere en tanto que el único Estado facultado para gravar dichos rendimientos es el Estado de residencia. En este sentido el Estado de la fuente debe excluirse de la imposición de estos rendimientos, siempre y cuando, al igual que en el caso de los dividendos e intereses, quien perciba el royalty sea el beneficiario efectivo de éstos y tenga la calidad de residente en el otro Estado contratante. La nueva redacción del artículo 12 queda de la siguiente manera:

«Las regalías procedentes de un Estado contratante y cuyo beneficiario efectivo es un residente del otro Estado contratante sólo pueden someterse a imposición en ese otro Estado».

115. Pasando al ámbito de la Unión Europea, en 2019 el Tribunal de Justica de la Unión Europea dictó una sentencia sobre el régimen común aplicable a los pagos de intereses y cánones realizados entre sociedades comunitarias. En este caso, el alto tribunal se pronunció sobre algunas propuestas relacionadas con la Directiva 2003/49 / CE del Consejo el 3 de junio de $2003^{37}$, sobre el pago de dichos intereses. En los artículos 1.4 y 1.5 de la mencionada directiva, se recogen dos definiciones distintas sobre beneficiario efectivo, dependiendo de si se trata de una sociedad o simplemente de un establecimiento permanente. En el primero de los artículos:

«Una sociedad de un Estado miembro será tratada como el beneficiario efectivo de los intereses o cánones únicamente si recibe tales pagos en su propio beneficio y no en calidad de intermediario, esto es de agente, depositario o mandatario».

116. Por su parte, el artículo 1.5 define que: «Un establecimiento permanente será tratado como el beneficiario efectivo de los intereses o cánones:

a) Si los créditos, derechos o usos de las informaciones que den origen a los pagos de intereses o cánones tienen relación efectiva con dicho establecimiento permanente, $\mathrm{y}$

b) Si los pagos de los intereses o cánones representan un ingreso respecto del cual dicho establecimiento permanente está sujeto en el Estado miembro en que esté situado a uno de los impuestos contemplados en el inciso iii) de la letra a) del artículo 3 de la directiva».

117. Por otra parte, hay que señalar que el artículo 2.1 de la Directiva 2003/48/CE sí existe una definición explícita de "beneficiario efectivo" y esta es la siguiente: «cualquier persona fisica que reciba un pago de intereses o cualquier persona física en cuyo beneficio se atribuya un pago de intereses, salvo que aporte pruebas de que dicho pago no se ha efectuado en beneficio suyo».

${ }^{37}$ Directiva 2003/48/CEE del Consejo de 3 de junio de 2003. Recuperado en: https://www.boe.es/doue/2003/157/L0003800048.pdf 
118. Es decir, debe demostrarse que se actúa por cuenta de otra persona, ya sea física, o jurídica, y adicionalmente debe comunicarse al pagador la identidad del verdadero beneficiario efectivo. En la resolución del tribunal, se incluyeron distintas alternativas para esclarecer el concepto de titularidad o beneficiario efectivo de los intereses; del mismo modo, se esclarece la existencia de abuso de Derecho y el concepto de «vulneración de las libertades comunitarias» en relación a la libre circulación de capitales entre los Estados miembros.

119. La propia resolución acumula una serie de casos de gran complejidad; entre los asuntos acumulados, por un lado están los casos: C-115/16, C-118/16, C-119/16 y C-299/16, en éstos, existe una estructura corporativa compleja donde se establecen operaciones con sociedades interpuestas para satisfacer los requisitos que recaen sobre el beneficiario efectivo de los intereses, para que éstos estén exentos de tributar en la fuente según la directrices de la Directiva 2003/49. Por otro lado, la Directiva 90/435/CEE del Consejo de 23 de julio de $1990^{38}$ relativa al régimen fiscal aplicable a las sociedades matrices y sus filiales en los Estados miembros acumula otros asuntos como los casos: C-116/16 y C-117/16.

120. En la Directiva 90/435/CEE, se permite que los beneficiarios repartidos por una sociedad filial a su sociedad matriz queden exentos de la retención en el origen. Además, del concepto de "beneficiario efectivo", El Tribunal de Justicia de la Unión Europea se pronunció sobre otras cuestiones como: el concepto "abuso Derecho":

121. En este caso, el TJUE, trabaja en los componentes del abuso de Derechos, y como demostrarlos: El alto tribunal, distingue entre factores objetivos y subjetivos; en cuanto a los factores subjetivos, éstos consisten en la voluntad de obtener beneficios que genera la normativa de la Unión Europea, a través de la creación de las condiciones necesarias para obtenerlos. En particular como subraya el TJUE, cuando los operadores económicos llevan a cabo actividades puramente formales o intencionales sin una justificación económica o comercial, su objetivo no es otro que obtener beneficios desleales por lo tanto obtener una ventaja indebida. Por su parte en los asuntos C-116/16, C-117/16, el tribunal no es exhaustivo, y puede identificar varios factores que permiten confirmar la existencia del abuso del Derecho como es el caso del uso de una sociedad interpuesta, es decir: «En la estructura del grupo entre la sociedad pagadora de los intereses y la entidad destinataria y beneficiaria efectiva de estos», para eludir el pago del tributo sobre los intereses.

122. En este caso, el tribunal europeo subraya que un convenio de doble imposición no excluye el abuso del Derecho o, en otras palabras, un convenio no puede evitar que pueda declararse la existencia de un abuso de Derecho si se acredita formalmente que se han efectuado operaciones sin justificación económica o comercial, con el objetivo de beneficiarse de las ventajas que ofrecen las propias directivas. Del mismo modo, TJUE en Sentencia de Justicia de 26 de febrero de 2019, declara que, la denegación de beneficios prevista en las Directivas 2003/49 / CEE y 90/435 / CEE, en base entre otras cosas a la existencia de circunstancias abusivas, donde se requiere que los Estados miembros afectados, prueben la existencia de los elementos constitutivos de las mismas circunstancias, considerando que los dividendos e intereses se pagaron a una sociedad "beneficiaria efectiva" 39 .

123. A este respecto, es interesante que las autoridades fiscales de los Estados miembros en cuestión no tengan la carga de la prueba en la identificación de los beneficiarios efectivos. Dado que el TJUE ha demostrado que las autoridades no pueden recopilar datos para identificar a los beneficiarios,

\footnotetext{
${ }^{38}$ Directiva 90/435/CEE del Consejo de 23 de julio de 1990. Recuperado en: https://eur-lex.europa.eu/LexUriServ/LexUriServ.do?uri=CONSLEG:1990L0435:20070101:ES:PDF

${ }^{39}$ STJUE (Gran Sala) de 26 de febrero de 2019. Contra T Danmark e y, Denmark Aps Asuntos acumulados C116/16 y $\mathrm{C} 117 / 16$. https://curia.europa.eu/juris/document/document.jsf?text $=\&$ docid=220426\&pageIndex $=0 \&$ doclang=ES\&mode $=$ req $\& \operatorname{dir}=\&$ occ $=$ first $\&$ part $=1 \& \operatorname{cid}=251018$
} 
es premisa demostrar que el supuesto beneficiario efectivo se trata de una sociedad instrumental a través de la cual, se ha cometido el abuso de Derecho. Por lo tanto, las autoridades no tienen obligación de identificar a la entidad beneficiaria de los intereses o dividendos.

124. Otra de las cuestiones de las que se pronuncia el TJUE es, sobre el "Principio General del Derecho de la Unión Europea de prohibición de las Prácticas abusivas”; si bien, el TJUE no excluye la aplicación de las disposiciones nacionales o convencionales creadas para prevenir el fraude y el abuso fiscal en las Directivas 2003/49/CEE y 90/45/ CEE, ello no implica la aplicación del Principio General del Derecho de la UE de prohibición de prácticas abusivas. Por lo tanto, la ausencia de tales disposiciones, no tienen relación alguna en relación con las obligaciones de las autoridades que tienen la facultad de denegar los derechos establecidos en las mencionadas directivas, cuando son invocados de modo fraudulento o abusivo. Es por ello, que las reclamaciones de las prestaciones prevista por la directiva solo pueden rechazarse si la legislación nacional a este respecto proporciona una base jurídica clara y específica.

125. Del mismo modo, el TJUE se pronunció sobre el asunto C-321/05 en Sentencia de 5 de julio de $2007^{40}$, estableciendo que la propia directiva no puede crear obligaciones personales para los particulares y el Estado parte en cuestión no puede involucrarlos. Sin embargo, el TJUE señala que, dado que los hechos abusivos no pueden fundamentar un Derecho previsto en el ordenamiento jurídico de la Unión Europea, la denegación de una ventaja prevista en la directiva no supondrá imponer una obligación a los particulares, ya que esta circunstancia se encuentra amparada por la aplicación del Principio General del Derecho de la UE, de prohibición de prácticas abusivas. En definitiva, este principio se debe oponer frente a aquellas personas que se amparan en determinadas normas para obtener ventajas que ofrece el Derecho comunitario, de hacerlo, la aplicación de estas normas, serían incongruentes con los objetivos para las que fueron creadas.

126. En relación a las libertades fundamentales, recogidas en el Tratado de Funcionamiento de la Unión Europea (TFUE) el TJUE recordó que, ante la constatación de una situación fraudulenta de abuso de Derecho, es legal que se invoque la aplicación de las libertades fundamentales para desafiar la retención en la fuente de intereses y dividendos. Por consiguiente, en tales casos, los Principios Generales del Derecho Comunitario, prohibirán el abuso de que las entidades impugnen la normativa fiscal sobre tributación de un Estado miembro de la fuente en relación con los dividendos. En consecuencia, los Estados miembros podrán denegar la exención de intereses y dividendos prevista en las Directivas 2003/49/CEE, y 90/435/CEE respectivamente no requiriéndose una norma anti-abuso para ello, en base Principio General de Prohibición de las Prácticas Abusivas. Finalmente, en el caso de España, «un establecimiento permanente será tratado como el beneficiario efectivo de los intereses o cánones», si los pagos de estos representan un ingreso del establecimiento situado en España, en cuyo caso, dichos rendimientos estarán sujetos al IRNR. Según establece la norma española, los intereses se considerarán rentas obtenidas en territorio español, cuando entre otros casos sean satisfechos por personas o entidades residentes en territorio español. Por lo tanto, tributarán con el tipo impositivo que establece la ley para este tipo de rendimientos obtenidos por la cesión a terceros de capitales propios. Por su parte, el artículo 14.1.f del Real Decreto Legislativo 5/2004, de 5 de marzo, por el que se aprueba el texto refundido de la Ley del Impuesto sobre la Renta de no Residentes (TRLIRNR) establece que ${ }^{41}$ :

«Se declararán exentos Los rendimientos de las cuentas de no residentes, que se satisfagan a contribuyentes por este impuesto, salvo que el pago se realice a un establecimiento permanente situado en territorio español, por el Banco de España, o por las entidades registradas a que se refiere la normativa de transacciones económicas con el exterior».

\footnotetext{
${ }^{40}$ STJUE (Sala primera) de 05 de julio de 2007. Procedimiento entre Hans Markus Kofoed y Skatteministeriet. Asunto C321/05. https://eur-lex.europa.eu/legal-content/ES/TXT/PDF/?uri=CELEX:62005CJ0321\&from=PL

${ }^{41}$ Real Decreto Legislativo 5/2004, de 5 de marzo, por el que se aprueba el texto refundido. Ley del Impuesto sobre la Renta de no Residentes. Recuperado en: https://www.boe.es/eli/es/rdlg/2004/03/05/5/con
} 
127. En este caso, la imposición final será cero, no superándose en ningún caso los posibles límites que se establezcan en los CDI's.

128. En cuanto a los dividendos percibidos por los contribuyentes, tendrán la consideración de rendimientos íntegros del capital mobiliario según establece el artículo 25 de la Ley 35/2006 de 28 de noviembre del Impuesto de la renta de las Personas Físicas (LIRPF). De dicho artículo se deriva que ${ }^{42}$ :

«Los dividendos pagados por una sociedad residente de un Estado contratante a un residente del otro Estado contratante pueden someterse a imposición en ese otro Estado si bien el impuesto exigido en ese otro Estado no podrá exceder de cierto límite (según el modelo de Convenio de la OCDE, el 15\% del importe bruto de los dividendos».

129. El artículo 14.1.h- $3^{\circ}$ de la Ley del Impuesto de la Renta de los No Residentes recoge una norma anti-abuso al no permitir la exención de los dividendos ${ }^{43}$ :

«Cuando la mayoría de los derechos de voto de la sociedad matriz se posean, directa o indirectamente, por personas físicas o jurídicas que no residan en Estados miembros de la Unión Europea o en Estados integrantes del Espacio Económico Europeo con los que exista un efectivo intercambio de información en materia tributaria, excepto cuando la constitución y operativa de aquella responde a motivos económicos válidos y razones empresariales sustantivas».

\section{EI nuevo concepto de establecimiento permanente en la economía digitial}

\section{Los nuevos factores del establecimiento permanente}

130. Una nueva concepción de establecimiento permanente surge a raíz de considerar ciertas actividades que anteriormente se realizaban de forma física, y que se han ido trasladando a plataformas digitales. Inicialmente la disyuntiva está en establecer un nexo para considerar si existe, o no, un establecimiento permanente en las transacciones que se efectúan a través de estas plataformas. En este apartado, abordaremos algunos de los factores más importantes que nos llevarán a encontrar el nexo para considerar que un servidor o página web, pueda configurarse como un posible establecimiento permanente. En este caso, la página web o servidor, puede estar radicado en un determinado territorio de forma física, o bien, tener una presencia significativa, aunque estemos hablando de actividades totalmente desmaterializadas. Sobre esta teoría, organizaciones como la OCDE a través de, el GEFED (Grupo de Expertos sobre la Fiscalidad de Economía Digital), debate y analiza distintas soluciones ante los problemas que se podrían plantear en las transacciones digitales y su tratamiento fiscal. En su informe de 20144.

«Las soluciones propuestas van desde la modificación de la definición de lo que se entiende por «establecimiento permanente (EP)» a la introducción de un nuevo nexo (o criterio de sujeción) en base a una «presencia significativa» en el país de la fuente, pasando por la aplicación de una retención en la fuente sobre las ventas de bienes y/o servicios digitales».

131. A continuación, haremos referencia a distintos factores técnicos, digitales, humanos y legales, que pueden actuar de nexo a la hora de establecer una presencia significativa y, por lo tanto, una nueva concepción de establecimiento permanente en el ámbito de la economía digital.

${ }^{42}$ Ley 35/2006, de 28 de noviembre, del Impuesto sobre la Renta de las Personas Físicas y de modificación parcial de las leyes de los Impuestos sobre Sociedades, sobre la Renta de no Residentes y sobre el Patrimonio. Recuperado en: https:/www. boe.es/eli/es/1/2006/11/28/35/con

${ }^{43}$ Real Decreto Legislativo 5/2004, de 5 de marzo, por el que se aprueba el texto refundido. Ley del Impuesto sobre la Renta de no Residentes. Recuperado en: https://www.boe.es/eli/es/rdlg/2004/03/05/5/con

${ }^{44}$ Proyecto OCDE/G20 de Erosión de la Base Imponible y Traslado de Beneficios Cómo abordar los desafíos Fiscales de la Economía Digital ACCIÓN 1: Objetivo del 2014. pág,24. Recuperado en: https://www.oecd.org/ctp/Action-1-DigitalEconomy-ESP-Preliminary-version.pdf 
132. Entre los «factores técnicos» a considerar que pueden hacer de nexo frente a una presencia económica significativa, podemos enumerar en primer lugar, las "transacciones realizadas": en este sentido, solo se tienen en cuenta los ingresos obtenidos por las transacciones digitales entre consumidores que utilizan las plataformas digitales; por lo tanto, solo se cuentan las transacciones que distinguen automáticamente ciertas actividades digitales, como ordenes por correo electrónico o ventas telefónica; por otra parte, se sugiere que los ingresos generados por los no residentes a través de las plataformas digitales se graven de manera similar para evitar desigualdades.

133. Seguidamente otro factor técnico que debe estar presente, es el "nivel del límite": en este caso los ingresos obtenidos mediante transacciones entre empresas no residentes y sus clientes se deben considerar brutos; por lo tanto, el límite inferior para considerar la presencia económica significativa debe tener un nivel alto, para minimizar la carga administrativa y garantizar que en las operaciones en las que se obtenga un impuesto mínimo, no exista el nexo; este límite debería fijarse según el mercado de cada país.

134. La OCDE deja entre ver que la economía digital facilita la elección de donde se origina la actividad económica ${ }^{45}$, por lo que los factores para establecer el límite inferior pueden medirse a nivel de grupo, en lugar de individualmente, puesto que hay menos riesgo de que las empresas fragmenten sus negocios para que no se excedan los límites de ingresos. Por otra parte, los contribuyentes tienen derecho a demostrar que no han fragmentado sus actividades económicas. En cuanto a la determinación del límite, hay que señalar que, en este caso suele resultar difícil para las administraciones conocer las transacciones y el volumen de las mismas, que se llevan a cabo en el país por parte de las empresas de la economía digital que no residen en dicho país; esto se debe fundamentalmente a la gran cantidad de transacciones que existen. Para facilitar la labor la OCDE, propone un sistema de registro para las plataformas que reúnan las peculiaridades necesarias para ser consideradas que tienen presencia económica significativa. En este registro, se aconseja que se utilice la información con la que cuentan la administración fiscal, sobre el pago de impuestos indirectos, ya que en estos registros estarían dadas de alta las empresas que operan en el mercado del país.

135. A la hora de determinar si existe o no una presencia económica significativa debemos tener en cuenta otros factores como los «factores digitales»; en cuanto a éstos, el comercio tradicional tiene una elevada dependencia, de ahí, su importancia, ya que cada vez son más las empresas que interactúan con sus clientes a través de promociones, publicidad, pagos etc. Sin embargo, en la economía digital, la forma de interactuar varía, pero mantiene algunos factores análogos en relación al comercio tradicional. Por lo tanto, pueden existir factores digitales que ayuden a determinar una presencia económica significativa.

136. Dentro de los factores digitales, nos encontramos con el nombre de "dominio local". En el comercio electrónico existe un equivalente al nombre de un comercio tradicional donde el cliente y la empresa entran en contacto; es un nombre de dominio; un nombre de dominio es una marca en Internet que sirve para identificar a la empresa. En este caso, los clientes usan su nombre de dominio para acceder a su página web, o a los servicios que esta ofrezca. En muchas ocasiones las entidades extranjeras pueden necesitar mejorar su plataforma protegiendo sus marcas, incluyendo un nombre de dominio, de este modo encontramos un nexo entre la empresa extranjera y el país del mercado.

137. Continuando con los factores digitales debemos mencionar la "plataforma local digital". Las entidades no residentes que operan a través del comercio electrónico, establecen variantes en sus páginas web en función de donde venden sus bienes y servicios; en ocasiones, el enfoque que adoptan las empresas para asegurar su posición en el mercado es muy particular y puede variar considerablemente de un país a otro, de este modo las empresas pueden publicar en sus páginas web singularidades

\footnotetext{
${ }^{45}$ Perspectivas de la OCDE sobre la economía digital 2015 pág.86. https://www.oecd.org/sti/ieconomy/DigitalEconomyOutlook2015_SP_WEB.pdf
} 
que no se muestran en la misma plataforma de otro país. Pon ultimo dentro de los factores digitales, la "forma de pago" de los bienes y servicios ofrecidos, es un factor muy importante a tener en cuenta en las transacciones realizadas a través del comercio electrónico. En este caso, las empresas extranjeras tienen interés en que sus clientes consumidores paguen sus productos del mismo modo que lo harían en el comercio tradicional. Hoy en día, muchas son las plataformas que ofrecen distintas formas de pago que reflejan la moneda local, los impuestos, y obligaciones que se tienen en cuenta en cada país.

138. En este sentido, cabe mencionar que la OCDE prevé que operar con formas locales de pago conllevaría una gran responsabilidad para las empresas, ya que estas, deben de cumplir con sus obligaciones administrativas y financieras. Para muchos países esta forma pago sería un indicativo para conocer si existe o no una presencia económica significativa.

139. Una vez vistos los fatores técnicos y digitales, haremos una breve referencia a otros factores que se basan el «usuario-consumidor». En este caso, conocer la inmersión en una plataforma extranjera digital de un país concreto, se puede medir por el número de usuarios activos que utilizan la plataforma en un periodo determinado. Hoy en día, la realidad es que las empresas digitales ofrecen escasa información al respecto sobre las visitas de sus clientes, algo que es contraproducente, ya que la información es importante para conocer oportunidades dentro de los mercados.

140. Finalmente, un factor relevante para determinar si existe o no presencia económica es la «celebración de contratos online». Este factor, está basado en la cláusula del "agente dependiente", que está prevista en el Modelo de Convenio de la OCDE en la forma de interpretar la definición de establecimiento permanente por parte de esta organización. En esta cláusula, se destaca que una empresa extranjera tiene presencia económica en un país cuando haya una persona actuando en nombre de ella, y a su vez concluya contratos de forma frecuente.

\section{La presencia digital significativa}

141. La economía digital presenta unos retos o desafíos que están plasmados en la acción 1 del Plan contra la erosión de la base imponible y el traslado de beneficios, conocido como Plan BEPS. Entre los desafíos, son cuatro los condicionantes tributarios que afectan a este nuevo modelo de negocio:

Primero: el nexo o criterio de sujeción, según la propia acción, la problemática está relacionada con la capacidad de las cadenas de valor digitales de generar, o no una presencia física que según la propia acción la considera desproporcionada en relación con los ingresos generados en la jurisdicción de la fuente; por lo tanto, una reducida presencia presenta una problemática valorativa.

Segundo: el tratamiento fiscal de los datos, este segundo desafío está estrechamente relacionado con el anterior, es decir el nexo, en este caso el problema surge cuando las empresas tratan estos datos mediante estrategias, donde la información que es objeto de explotación comercial y que proviene de otras jurisdicciones puede ser interpretada de forma distinta a la del origen de los datos.

Tercero: la calificación de las rentas derivadas del nuevo modelo económico digital: Según la propia acción, «los nuevos modelos de negocio plantean dudas sobre la calificación apropiada de ciertas operaciones y determinados pagos desde el punto de vista de la normativa interna y en virtud de los convenios fiscales» ${ }^{46}$.

Cuarto: la recaudación del Impuesto de Valor Agregado; en el caso del IVA, el reto se plantea cuando los consumidores privados adquieren productos online a proveedores situados en el extranjero.

${ }^{46}$ Proyecto OCDE/G20 de Erosión de la Base Imponible y Traslado de Beneficios. Cómo abordar los desafíos fiscales de la Economía Digital, pág. 145. Recuperado en: https://www.oecd.org/ctp/Action-1-Digital-Economy-ESP-Preliminary-version.pdf 
142. Autores como OLBERT Y SPENGER ${ }^{47}$, critican duramente los desafíos planteados en la Acción 1 de BEPS, puesto que, para ambos: «la política relativa a los modelos de negocio digitales debe seguir de cerca el análisis de la organización, y características económicas de los desarrollos descritos. Mientras que las oportunidades de BEPS inherentes a la económica digital, los desafios más amplios solo se describen en un nivel abstracto. Por otra parte, se necesitaría más precisión para determinar el tratamiento fiscal exacto de todas las transacciones de una empresa digital y multinacional».

143. Aunque hayamos conseguido avanzar en la calificación de las rentas internacionales de la economía digital, existen problemas a la hora de establecer la imposición indirecta de algunas de estas rentas en relación al IVA. En este caso a tendencia de los Estados es aplicar el criterio de destino del IVA.

144. Otra problemática la encontramos en la creación de mecanismos de comunicación más eficientes entre las administraciones tributarias, y entre éstas y los contribuyentes. Hoy aun seguimos sin encontrar la solución más adecuada para dar respuesta al problema que surge a la hora de establecer el criterio de sujeción más adecuado dentro de la economía digital. Sobre la Acción 1 BEPS, la OCDE mantuvo en su momento varias opciones para enmendar la definición de establecimiento permanente, y abordar los desafíos digitales de forma más amplia. En base a la acción 7 del plan, las excepciones al estatus del establecimiento permanente fueron modificadas en el artículo 5 del Modelo. En el futuro, solo se considerarán actividades generales de un EP, las que conlleven una preparación y se exceptuará el carácter auxiliar. En un primer momento, se propuso una posible modificación de las excepciones establecidas en el apartado 4 del artículo 5 del Modelo de Convenio OCDE ${ }^{48}$.

145. El artículo 5.4 del Modelo de Convenio, recoge aquellas excepciones a las que se les debe atribuir la expresión establecimiento permanente. Como resultado, una función que antes se consideraba auxiliar como la logística, podría constituir un establecimiento permanente si una infraestructura logística en su buen desempeño fuese esencial al modelo de negocio, Por otra parte, se introduce una regla anti-fragmentación, para complementar la modificación de excepciones al estado de establecimiento permanente.

146. Esta regla está dirigida a dar la oportunidad de digitalizar empresas para distribuir su cadena de valor entre varias entidades comerciales y jurisdicciones. En este caso el Grupo de Expertos sobre la Fiscalidad de la Economía Digital (GEFED) de la OCDE propone establecer un nuevo nexo en base a una presencia virtual significativa para dar respuesta a determinadas situaciones que se producen en ciertas actividades comerciales que se efectúan exclusivamente de forma digital. estas actividades que se consideran desmaterializadas, son aquellas donde las empresas digitales suelen precisan de unos mínimos elementos físicos en el Estado de la fuente para realizar su actividad principal con independencia de que estos elementos físicos (oficina edificios) se encuentren o no en el Estado de la fuente. Según la OCDE, se pueden considerar actividades desmaterializadas:

i. La actividad principal de la empresa se basa enteramente o en su mayor parte en bienes y/o servicios digitales.

\footnotetext{
${ }^{47}$ Vid. M. Olbert, y C. Spengel (2017) "International Taxation in the Digital Economy: Challenge Accepted”, World Tax Journal, (Volumen 9), núm,1, pág. 11.

${ }^{48}$ Artículo 5.4 MC OCDE: se considera que la expresión "establecimiento permanente" no incluye: a) la utilización de instalaciones con el único fin de almacenar, exponer o entregar bienes o mercancías pertenecientes a la empresa; b) el mantenimiento de un depósito de bienes o mercancías pertenecientes a la empresa con el único fin de almacenarlas, exponerlas o entregarlas; c) el mantenimiento de un depósito de bienes o mercancías pertenecientes a la empresa con el único fin de que sean transformadas por otra empresa; d) el mantenimiento de un lugar fijo de negocios con el único fin de comprar bienes o mercancías o de recoger información para la empresa; e) el mantenimiento de un lugar fijo de negocios con el único fin de realizar para la empresa cualquier otra actividad de carácter auxiliar o preparatorio; f) el mantenimiento de un lugar fijo de negocios con el único fin de realizar cualquier combinación de las actividades mencionadas en los subapartados a) a e), a condición de que el conjunto de la actividad del lugar fijo de negocios que resulte de esa combinación conserve su carácter auxiliar o preparatorio. Recuperado en: https://www.globbal.co/wp-content/uploads/2018/04/Modelo-de-CDI-OCDE-versi\%C3\%B3n-abreviada.pdf
} 
ii. No entran en juego actividad o elemento físico alguno en la creación de los bienes y servicios o en su entrega y prestación, respectivamente, aparte de la existencia, uso o mantenimiento de servidores y sitios web u otras herramientas informáticas, así como la recopilación, procesamiento y comercialización de datos geolocalizados.

iii. Los contratos se celebran generalmente a distancia, a través de Internet o por teléfono.

iv. Los pagos se efectúan exclusivamente mediante tarjetas de crédito u otros medios de pago electrónicos gracias a formularios en línea en los sitios web correspondientes o a plataformas vinculadas o integradas en los mismos.

v. Los sitios web representan el único medio utilizado para relacionarse con la empresa; no intervienen ninguna tienda o agencia física en las actividades principales, a excepción de las oficinas situadas en los países en que se encuentren la matriz o la compañía explotadora.

vi. Todos o la mayor parte de los beneficios son imputables a la entrega de bienes o prestación de servicios digitales.

vii. El cliente no tiene en cuenta el domicilio legal o residencia fiscal y la ubicación física del vendedor, que no influyen en sus elecciones.

viii. El uso efectivo del bien digital o la prestación del servicio digital no precisan de una presencia física o de la utilización de un producto material distinto de un ordenador, dispositivos móviles u otras herramientas informáticas.

147. La OCDE menciona que estas modificaciones pueden ir más allá de los casos BEPS, y no solo se limita a evaluar las modificaciones del concepto de establecimiento permanente, sino que, sobre la base de sus enfoques iniciales, presenta un nuevo nexo imponible basado en el concepto de presencia económica significativa:

«Al número total de contratos celebrados a distancia relativos a bienes y servicios digitales, a la participación activa de un número considerable de usuarios (tales como el número de cuentas activas para las plataformas sociales, el número de visitantes a los sitios web o el número de usuarios de herramientas en línea) y el nivel global de consumo de bienes o servicios digitales de la empresa en el país de la fuente» ${ }^{49}$.

148. La OCDE menciona que, una vez que se establece tal nexo, la determinación de la renta atribuible no es una tarea trivial; las reglas y principios existentes no serían análogamente aplicables sin realizar ajustes importantes debido a la falta de presencia física. En relación con el trabajo de la OCDE y en base a BEPS, autores como HONGLER y PISTONE, presentan un informe elaborado sobre cómo expandir el concepto de "establecimiento permanente", para preservar adecuadamente la soberanía de los Estados de origen, y gravar los ingresos empresariales digitales. Aunque el trabajo se relaciona directamente con el proyecto BEPS, ambos autores buscan una revisión principalmente de los principios para la asignación de Derechos tributarios. Los autores proponen el establecimiento permanente como un medio para asignar Derechos tributarios que requieren una desviación del concepto de un lugar fijo de negocios, basado en características físicas como respuesta a los cambios estructurales de la economía digital.

149. A la hora de crear un negocio digital, los Estados pueden justificar la creación de un establecimiento permanente de acuerdo tanto con la teoría de la fuente, como con la teoría del beneficio. Por un lado, la teoría de la fuente debería abarcar a las empresas digitales sin creación de valor en un entorno moderno y de menor presencia física; por otro lado, en las actividades digitales no físicas también se benefician de los Estados con un sistema legal estable, en la ejecución de pagos, en el suministro de energía o en infraestructuras que son importantes en este modelo de negocio.

49 Proyecto OCDE/G20 de Erosión de la Base Imponible y Traslado de Beneficios Cómo abordar los desafíos Fiscales de la Economía Digital ACCIÓN 1: Objetivo del 2014, pág,157. Recuperado en: https://www.oecd.org/ctp/Action-1-DigitalEconomy-ESP-Preliminary-version.pdf 
150. Por lo tanto, siguiendo esta regla, una empresa que opera a través de plataformas digitales, bases de datos, plataformas de publicidad en línea, se consideraran un establecimiento permanente, si cuentan con una base de 1000 usuarios al mes, y un cierto umbral de ingresos en un determinado Estado. Si se establece este nexo, ni los precios de transferencia actuales, ni las reglas para la asignación de activos, funciones y riesgos, ni el concepto alternativo de distribución del formulario, serían adecuados para la asignación de ingresos debido a la naturaleza no física de la tecnología digital.

151. HONGLER y PISTONE, abogan por la aplicación del método de división de beneficios transaccionales, que debe revisarse para tener en cuenta la gran importancia de la inherente creación de valor del propio mercado. Se considera que una asignación de ingresos por adelantado de un tercio de las ganancias de una empresa digital a la jurisdicción del mercado, está en línea con los principios económicos y por lo tanto: «la existencia de tales beneficios, incluso en ausencia de presencia física, prueba que los nuevos modelos de negocio desarrollados por la economía digital no deberían impedir que un estado ejercer sus poderes impositivos sobre dichos ingresos comerciales con el fin de contrarrestar el costo soportado para prestar sus servicios» ${ }^{50}$.

152. Aunque la recaudación del impuesto y la distribución entre varios países de mercado podrían implican desafíos prácticos, los autores también ven la división inicial y la asignación de ganancias como una opción viable para garantizar la aplicación global de los impuestos. Para los mencionados autores, «la ventaja de dicho sistema es la recaudación de impuestos simple y rentable. Además, sobre la base del supuesto de que los impuestos que se recaudan a nivel de una empresa, el riesgo de no exigibilidad es bajo».

153. De los comentarios sobre el artículo 5 del MCOCDE, se desprende que si bien se han intentado modificar la configuración del nexo tradicional, y el concepto de "lugar fijo de negocios" de la empresa, no se ha llegado a evolucionar hasta el punto de cubrir de forma adecuada y completa los espacios digitales; la presencia significativa sigue siendo un elemento esencial para determinar un lugar de establecimiento permanente, con independencia del lugar donde se genere materialmente el valor económico. Por lo tanto, es necesario establecer un análisis de cada caso en particular, teniendo en cuenta las características y elementos específicos para determinar si existe o no un establecimiento permanente; del mismo modo, habrá que tener en cuenta las reticencias de los Estados que disciernen de la interpretación de la OCDE, para así, conocer su propio criterio de interpretación en relación a este concepto.

154. Considerando la facilidad de ocultar el elemento "permanencia" necesaria para constituir un lugar fijo de negocios, y la dificultad para concretar si se realizan habitualmente contratos en nombre de la empresa, o bien si se trata de una actividad auxiliar o preparatoria, se debatió sobre la idea de un "establecimiento permanente virtual", basado en el término "business presence test" (presencia comercial significativa). En base a esta idea Se entenderá que una empresa dedicada a una actividad totalmente desmaterializada cuenta con una presencia virtual significativa en un determinado país cuando ${ }^{51}$ :

1. Se firme a distancia un número significativo de contratos de suministro de bienes o servicios digitales totalmente desmaterializados entre la empresa y un cliente residente en ese país a efectos fiscales.

2. Los bienes o servicios digitales de la empresa se utilicen o consuman, en gran medida, en dicho país.

${ }^{50}$ Vid. P. Hongler y P. Pistone (2015) Blueprints for a New PE Nexus to Tax Business Income in the Era of the Digital Economy, pág.22 y 37, White Papers IBFD. Recuperado en: https://www.ibfd.org/sites/ibfd.org/files/content/pdf/Redefining the_PE_concept-whitepaper.pdf

${ }^{51}$ Proyecto OCDE/G20 de Erosión de la Base Imponible y Traslado de Beneficios Cómo abordar los desafíos Fiscales de la Economía Digital ACCIÓN 1: Objetivo del 2014, pág,158. Recuperado en: https://www.oecd.org/ctp/Action-1-DigitalEconomy-ESP-Preliminary-version.pdf 
3. Los clientes situados en ese país efectúen pagos sustanciales en favor de la empresa como contraprestación por las obligaciones contractuales derivadas del suministro de bienes o servicios digitales en cuanto parte de la actividad principal de la empresa en cuestión.

4. Una sucursal de la empresa ubicada en dicho país desarrolle actividades secundarias, como es el caso de funciones de asesoramiento y comercialización dirigidas a los clientes residentes del país en cuestión estrechamente vinculadas a la actividad principal de la empresa.

155. El Grupo de Expertos sobre la Fiscalidad de la Economía Digital (GEFED) estudió igualmente una variante de esta posible solución consistente en crear un nuevo nexo fiscal para las empresas dedicadas a una actividad digital totalmente desmaterializada, siempre y cuando la entidad desarrolle una actividad significativa en el país, utilizando para ello datos de carácter personal obtenidos mediante el seguimiento regular y sistemático de los usuarios de Internet en ese país. Finalmente, otra de las propuestas del GEFED, pasa por sustituir el concepto existente de EP por un criterio basado en la "presencia significativa" para atender los cambios que se producen en las relaciones con los clientes en el entorno digital, sin dejar de apoyarse en la presencia física. Los criterios para llevar a cabo el cambio de concepto incluirían ${ }^{52}$ :

- Las relaciones con los clientes o usuarios durante al menos seis meses, acompañadas de una cierta presencia física en el país, de forma directa o por medio de un agente dependiente.

- La venta de bienes o servicios por medios que implican una cercanía a los clientes en el país, entre ellos (i) un sitio web en el idioma local, (ii) un servicio de entrega por parte de los proveedores ubicados en la jurisdicción, (iii) servicios bancarios y otros varios ofrecidos por los proveedores en ese país, o (iv) suministro de bienes o servicios procedentes de proveedores ubicados en dicho país.

- Suministro de bienes o servicios a los clientes radicados en un determinado país fruto de una actividad sistemática de recogida de datos o aportaciones de contenidos por parte de personas situadas en el país en cuestión.

156. Jurisprudencialmente nos encontramos con casos como el que surge en el año 2007, cuando mediante un procedimiento inspector la Administración Tributaria española, reclama una deuda tributaria al grupo internacional DELL, un grupo cuya sede matriz en encuentra ubicada en Irlanda (DPI). Se da el caso de que este grupo cuenta con una filial en España DESA, que tributaba por las comisiones que recibía en calidad de mero comisionista. La principal cuestión que se plantea es la muy posible existencia de un Establecimiento permanente del DELL en España en base a aplicar el CDI hispano-irlandés. En este caso, queda muy clara la Sentencia del Tribunal Supremo dictada en la sala de lo Contencioso el 20 de junio de $2016^{53}$. Lo primordial para el alto tribunal era conocer si DELL cuya residencia fiscal se encuentra en Irlanda, operaba a través de Establecimiento permanente, o bien lo hacía a través de su filial DESA.

157. En los fundamentos de la sentencia queda clarificado que el modo operandi de DELL, consistía en utilizar las instalaciones de su filial DESA en España para realizar funciones de: promoción, venta, captación de clientes, gestión de pedidos, control y recepción de productos, así como la distribución de los mismos, el marketing y la publicidad.

158. En la propia sentencia, se recogen los argumentos que en su día ofreció el Tribunal Económico Administrativo Central (TEAC), en su resolución de 15 de marzo de 201254. Para el TEAC, la

\footnotetext{
${ }^{52}$ Proyecto OCDE/G20 de Erosión de la Base Imponible y Traslado de Beneficios Cómo abordar los desafíos Fiscales de la Economía Digital ACCIÓN 1: Objetivo del 2014, pág,159. Recuperado en: https://www.oecd.org/ctp/Action-1-Digital-EconomyESP-Preliminary-version.pdf

${ }^{53}$ STS, 2861/2016 de 20.06.2016, Recuperado en: https://www.poderjudicial.es/search/AN/openCDocument/47c54a4d73e 1a196edebf95c01daaaa80cf6f6c206d954a4

${ }^{54}$ Resolución núm,00/2107/2007 de Tribunal Económico-Administrativo Central. Recuperado en: https://serviciostelematicosext.hacienda.gob.es/TEAC/DYCTEA/criterio.aspx?id=00/02107/2007/00/0/1\&q=s\%3d1\%26rn\%3d\%26ra\%3d\%26fd\%
} 
página web, pese a su intangibilidad, puede ser un lugar de negocios en tanto que se realicen operaciones comerciales desde la misma.

159. El TEAC ampara sus argumentos, por un lado, reconociendo los Comentarios al MCOCDE, que se hacen del establecimiento permanente, puramente automático y sin necesidad de intervención humana, pese que a continuación afirme que de la documentación obrante en el expediente se desprende la existencia de personal al servicio de la web, y por otro lado la consideración que España tiene sobre los Comentarios del MCOCDE donde la posible existencia de establecimiento permanente es retirada de los Comentarios del Modelo de la OCEDE de 2010, por lo que las pretensiones de considerar a una web como establecimiento decaerán En el apartado quinto de los Fundamentos el Tribunal Supremo entra a cuestionar la existencia o no de un "agente dependiente" por parte de la filial española, lo hace interpretando el artículo 5.5 del MCOCDE. En este caso para el tribunal:

«Lo relevante, por tanto, no es tanto que medie un determinado contrato, un determinado vínculo contractual, sino la vinculación funcional, que el agente posea poderes suficientes para vincular al comitente, dentro del desarrollo habitual de la actividad empresarial conforme a las instrucciones y bajo el control del mismo; de suerte que ha de atenderse no tanto a las formas que unen a comitente y agente, como al análisis funcional y fáctico que definen la relación existente realmente manifestada por el alcance y límites de las instrucciones, grado de control, asunción de riesgos y/u organización empresarial, de la que surge la dependencia que debe ser de alcance sustancial y no meramente preparatorio o auxiliar».

160. Del mismo modo el Tribunal Supremo insiste en la necesidad de atender a la realidad del contrato, y de las relaciones prestadas por la filial española en relación con el funcionamiento del grupo empresarial, dejando a un lado interpretaciones formalistas y literales del MCOCDE. Esta circunstancia queda patente en el fundamento quinto:

«Todo lo cual responde a la finalidad y función a cumplir en la regulación de la fiscalidad internacional, que pretende la distribución equitativa de las cargas impositivas y de los beneficios empresariales entre los Estados, en un escenario muy diferente al existente en el momento en el que surgen los Convenios de Doble Imposición, un mercado globalizado en el que las compañías multinacionales tratan de trasladar los beneficios obtenidos en otros Estados hacia uno de baja tributación. No cabe, pues, la interpretación estrictamente formalista-literal y estática que pretende la parte recurrente, aun cuando en momentos determinados tribunales de otros países, noruegos o franceses, como indica la parte recurrente hayan acudido a dichas interpretaciones de Convenios de Doble Imposición análogos al que nos ocupa».

161. Tanto la Audiencia Nacional ${ }^{55}$, como el Tribunal Supremo mediante recurso de casación, entienden que DPI con residencia en Irlanda, posee un establecimiento permanente en territorio español; de este modo, el alto tribunal rechaza el precepto por el cual se pretendía evitar la existencia de un agente dependiente y por lo tanto, la existencia de un establecimiento permanente, cuando éste actuase en su propio nombre aunque por cuenta de terceros, adelantándose a lo que posteriormente se recogerá en la acción 7 de Proyecto BEPS $^{56}$, y que provocaría la posterior modificación del artículo 5 del MCOCDE.

$3 \mathrm{~d} 15 \% 2 \mathrm{f03} \% 2 \mathrm{f} 2012 \% 26 \mathrm{fh} \% 3 \mathrm{~d} 15 \% 2 \mathrm{f03} \% 2 \mathrm{f} 2012 \% 26 \mathrm{u} \% 3 \mathrm{~d} \% 26 \mathrm{n} \% 3 \mathrm{~d} \% 26 \mathrm{p} \% 3 \mathrm{~d} \% 26 \mathrm{c} 1 \% 3 \mathrm{~d} \% 26 \mathrm{c} 2 \% 3 \mathrm{~d} \% 26 \mathrm{c} 3 \% 3 \mathrm{~d} \% 26 \mathrm{tc} \% 3$ $\mathrm{d} \% 26 \mathrm{tr} \% 3 \mathrm{~d} 1 \% 26 \mathrm{tp} \% 3 \mathrm{~d} \% 26 \mathrm{tf} \% 3 \mathrm{~d} \% 26 \mathrm{c} \% 3 \mathrm{~d} 2 \% 26 \mathrm{pg} \% 3 \mathrm{~d}$

${ }^{55}$ SAN, 2153/2015, de 08.06.2015, Recuperado en: https://www.poderjudicial.es/search/doAction?action=contentpdf\&d atabasematch $=\mathrm{AN} \&$ reference $=7433819 \&$ links $=$ establecimiento $\% 20 \mathrm{Y} \% 20$ permanente $\% 20 \mathrm{Y} \% 20 \mathrm{no} \% 20$ residentes\&optimize $=20150714 \&$ publicinterface $=$ true

${ }^{56}$ beps acción 7: impedir la elusión artificiosa del estatuto de establecimiento permanente (EP) 31 octubre 2014 - 9 enero 2015, pág,22. El párrafo 4 no se aplicará a un lugar fijo de negocios que una empresa utilice o mantenga si esa misma empresa o una empresa asociada lleva a cabo actividades comerciales en el mismo lugar o en otro lugar del mismo Estado contratante, y a) ese lugar u otro lugar constituye un establecimiento permanente de la empresa o de la empresa asociada con arreglo a lo dispuesto en el presente artículo, o b) la actividad global resultante de la combinación de las actividades llevadas a cabo por las dos empresas en el mismo lugar, o por la misma empresa o por empresas asociadas en los dos lugares. Recuperado en: https://www.oecd.org/ctp/treaties/proyecto-preliminar-accion-7-impedir-elusion-artificiosa-estatuto-ep.pdf 


\section{Conclusiones}

162. Está claro que la economía digital nos ha ofrecido nuevos modelos de negocio que deben estar sujetos a un constante y riguroso estudio, debido a los constantes cambios que se han producido por tratarse de una economía global. Este estudio afecta tanto a los modelos de negocio que utilizan las empresas digitales, como a la fiscalidad de sus rentas. Una fiscalidad que preocupa a las autoridades de los Estados, ya que la elevada cantidad de operaciones y actividades que se llevan a cabo a través de la economía digital generan unos beneficios directos específicos que deben ser gravados.

163. Ante este contexto, son varios los retos y desafíos que se plantean a la hora de establecer la tributación de los beneficios procedentes de la economía digital, y que comienzan con una desterritorialización de la actividad económica y fiscal. Es decir, nos encontramos ante retos como, establecer en primer lugar quien es el "beneficiario efectivo" de las rentas obtenidas y, en segundo lugar, donde deben tributarse las rentas, más aun, teniendo en cuenta que no existe una presencia física en este modelo de negocio. Estas circunstancias que diferencian el comercio digital, del tradicional, han generado dificultades a la hora de plantear donde se debe considerar que se está desarrollando una actividad económica susceptible de tributar, ya que las empresas digitales están, utilizado comportamientos "ilícitos" que han dificultado a las autoridades fiscales obtener la información necesaria sobre sus rentas, de cara a su obligación fiscal. Estas circunstancias generan una erosión en las arcas tributarias de los Estados fundamentalmente por la inexistencia de un espacio físico o establecimiento permanente.

164. Para dar respuesta a este desafío, Organismos internacionales como la OCDE intentan a través de su Modelo de Convenio y el Plan BEPS, ofrecer una interpretación de cómo se debe distribuir la potestad tributaria de las rentas procedentes del comercio digital; y una interpretación del concepto "beneficiario" para crear un criterio específico común y global sobre el tratamiento de dichas rentas.

165. En una primera aproximación la organización intergubernamental, utiliza el término beneficiario final, como un requisito subjetivo para que los residentes de un Estado parte, puedan beneficiarse de una tasa impositiva reducida relacionada con los ingresos recibidos en el país de origen; circunstancias y requisitos que quedaran plasmados en los artículos 10, 11, y 12 del Modelo de Convenio de 1956; En 1977, se comenzaran a introducir modificaciones en relación al término beneficiario con la finalidad de prevenir la evasión y elusión fiscal, cada vez más acentuada en este tipo de economía digital. Además, de cambiar el concepto beneficiario "final" por beneficiario "efectivo", en las nuevas versiones la OCDE, se reconoce la tributación compartida entre el Estado de la fuente y el Estado de residencia en la medida de que este último, será considerado beneficiario efectivo, por lo que se aconseja al Estado de la fuente aplicar las deducciones convenientes para evitar la doble tributación.

166. Otros de los desafíos que se plantean en relación a la tributación de las rentas digitales se plantea a la hora de establecer una configuración actual de establecimiento permanente. En el año 2014, el Grupo GEFED (Grupo de Expertos sobre la Fiscalidad de la Economía Digital) de la OCDE, analiza el concepto "presencia virtual significativa", para dar una solución a la tributación de las rentas "virtuales". Este grupo de expertos, propone la creación de un nuevo "nexo" en base a dicha presencia significativa; para ello, sugiere la creación de un registro para aquellas plataformas digitales que reúnan las peculiaridades necesarias para ser consideradas que tienen presencia económica significativa. En este caso se deberán tener en cuenta distintos «factores técnicos» como pueden ser: las transacciones realizadas, o el nivel del límite de rentas; «factores digitales» como el dominio local, o la plataforma local digital, y «factores humanos» como la cláusula de "agente dependiente". Por lo tanto, GEFED propone sustituir el concepto existente de establecimiento permanente, por un criterio basado en la "presencia significativa" para atender así a los cambios que se producen en las relaciones con los clientes en el entorno digital, sin dejar de apoyarse en la presencia física. 
167. En el presente documento hemos intentado dar respuesta a estos y otros desafíos que presentan en la economía digital. A pesar de los esfuerzos realizados por los Estados y organizaciones como la OCDE, no tenemos una solución fácil e inmediata a este problema, y nuestro objetivo debe enfocarse a resolver los problemas existentes, proponiendo alternativas concretas ante los retos planteados, que permitan buscar una solución al desequilibrio de soberanía fiscal que existe en relación a la tributación de las rentas digitales.

168. Sin bien, podemos decir que las modificaciones efectuadas en un primer momento suponen un importante paso en relación a la innovación del control tributario en materia de elusión y evasión fiscal, del mismo modo, podemos afirmar que no son suficientes, ya que es complicado construir de forma solida una norma fiscal internacional que permita una imposición justa, segura y controlada. En este caso, se están dando pasos importantes como el que se ha producido por parte del G-7 en su reunión de Londres celebrada el día 5 de junio de 2021, donde se acuerdan establecer medidas que supondrán un antes y un después en la forma de tributar las rentas digitales. En este sentido, y como ejemplo, se prevé establecer un tipo impositivo mínimo del 15\% del IS en el lugar o Estado donde se obtengan los beneficios, para luchar contra el fraude y la evasión fiscal.

169. Esta novedosa medida supone que empresas como Amazon, Google o Facebook, no podrán tributar por sus operaciones realizadas en los territorios donde obtengan beneficios en condiciones más ventajosas que aquellas otras empresas con presencia física o establecimiento permanente en esos mismos territorios. Aun así, sería importante establecer nuevos sistemas y obligaciones formales de información frente a las administraciones tributarias, aplicados al comercio electrónico, tanto para proveedores de pago online, como para los servidores o plataformas digitales.

170. Del mismo, modo creemos que sería conveniente establecer nuevos sistemas de cooperación y colaboración internacional, donde los convenios de doble imposición cobren protagonismo frente a las nuevas obligaciones normativas, que deben ser propuestas de forma consensuada tanto por los Estados, como por otras entidades Supranacionales. Finalmente, deberían crearse herramientas que se utilicen tanto en las redes, como en el comercio electrónico, que faciliten la aparición de nuevos métodos de control, aplicados por las autoridades tributarias de los Estados.

171. A modo de reflexión, aunque es cierto que nos encontramos ante el reto de establecer una correcta tributación de las rentas en el comercio electrónico, el problema no debe fundamentarse en la metodología para llevar a cabo las operaciones comerciales digitales, ya que se podrían producirse discriminaciones a la hora de establecer diferentes imposiciones por las operaciones llevadas a cabo en el ámbito del comercio digital; más bien, consideramos que se debería incidir en como establecer un consenso para aplicar una tributación homogénea que no dé lugar, a que las empresas que operan a través de la redes puedan elegir aquellas jurisdicciones fiscales que les sean más favorables para sus intereses económicos. 